Article

\title{
Continuous Catalytic Deoxygenation of Waste Free Fatty Acid-Based Feeds to Fuel-Like Hydrocarbons Over a Supported Ni-Cu Catalyst
}

\author{
Ryan Loe 1,2, Yasmeen Lavoignat ${ }^{1}$, Miranda Maier ${ }^{1}$, Mohanad Abdallah ${ }^{1}$, Tonya Morgan ${ }^{1}$, \\ Dali Qian ${ }^{1}$, Robert Pace ${ }^{1,2}$, Eduardo Santillan-Jimenez ${ }^{1}$ (D) and Mark Crocker ${ }^{1,2, * \mathbb{D}}$ \\ 1 Center for Applied Energy Research, University of Kentucky, 2540 Research Park Drive, Lexington, \\ KY 40511, USA; ryan.loe@uky.edu (R.L.); yaslav@orange.fr (Y.L.); miranda.maier@uky.edu (M.M.); \\ mohanad.abdallah@uky.edu (M.A.); tonya.morgan@uky.edu (T.M.); dali.qian@uky.edu (D.Q.); \\ robert.pace@uky.edu (R.P.); esant3@uky.edu (E.S.-J.) \\ 2 Department of Chemistry, University of Kentucky, Lexington, KY 40506, USA \\ * Correspondence: mark.crocker@uky.edu; Tel.: +1-859-257-0295
}

Received: 18 January 2019; Accepted: 22 January 2019; Published: 30 January 2019

\begin{abstract}
While commercial hydrodeoxygenation (HDO) processes convert fats, oils, and grease (FOG) to fuel-like hydrocarbons, alternative processes based on decarboxylation/decarbonylation $\left(\mathrm{deCO}_{\mathrm{x}}\right)$ continue to attract interest. In this contribution, the activity of $20 \% \mathrm{Ni}-5 \% \mathrm{Cu} / \mathrm{Al}_{2} \mathrm{O}_{3}$ in the $\mathrm{deCO}_{x}$ of waste free fatty acid (FFA)-based feeds-including brown grease (BG) and an FFA feed obtained by steam stripping a biodiesel feedstock - was investigated, along with the structure-activity relationships responsible for $\mathrm{Ni}$ promotion by $\mathrm{Cu}$ and the structural evolution of catalysts during use and regeneration. In eight-hour experiments, near quantitative conversion of the aforementioned feeds to diesel-like hydrocarbons was achieved. Moreover, yields of diesel-like hydrocarbons in excess of $80 \%$ were obtained at all reaction times during a BG upgrading experiment lasting $100 \mathrm{~h}$, after which the catalyst was successfully regenerated in situ and found to display improved performance during a second $100 \mathrm{~h}$ cycle. Insights into this improved performance were obtained through characterization of the fresh and spent catalyst, which indicated that metal particle sintering, alloying of $\mathrm{Ni}$ with $\mathrm{Cu}$, and particle enrichment with $\mathrm{Cu}$ occur during reaction and/or catalyst regeneration.
\end{abstract}

Keywords: free fatty acids; brown grease; deoxygenation; decarboxylation; decarbonylation; nickel; copper; hydrocarbons

\section{Introduction}

Due to the interest in renewable fuels resulting from environmental and sustainability concerns and the high fuel demand of the transportation sector, biofuel production requires multiple feed sources. Currently, edible feeds are used in considerable amounts to achieve lower greenhouse gas emissions relative to liquid fossil fuels [1,2]. However, these feeds are needed to meet the food demand of a growing population, food prices rising when edible crops are used for fuel production [3]. Inedible oleaginous plants that thrive in arid soil avoid disrupting the food supply $[1,4]$, but their current scale of cultivation is insufficient. Microalgae produce more oil than terrestrial crops, but energy and cost challenges associated with their cultivation remain to be overcome $[5,6]$. Thus, additional inedible feeds are required to meet fuel demand, fats, oils, and grease (FOG) waste streams showing great promise due to their low cost and widespread availability.

Noteworthy oleaginous waste streams include yellow grease (waste cooking oil) and brown grease (FOG collected from grease traps, i.e., devices engineered to separate insoluble oils from commercial kitchen wastewater streams [7]). Although a significant fraction of yellow grease (YG) is currently 
converted to renewable fuels, brown grease (BG) remains underutilized. Indeed, the U. S. Department of Energy has estimated that 1.7 million tons of BG are produced in the U.S. each year [7], nearly all of which is either incinerated or transported to landfills. Therefore, the valorization of BG is of significant interest. Biodiesel represents the primary renewable fuel to which oleaginous feedstock is currently converted, mainly via the base-catalyzed transesterification of triglyceride-based feeds. However, the high free fatty acid (FFA) content of BG is problematic in this process, as it results in catalyst deactivation and biodiesel contamination with soaps [8]. Indeed, FFAs are typically separated from triglyceride-based streams via steam stripping. The resulting FFAs can be converted to biodiesel via acid-catalyzed esterification, but this process is not widely utilized. Therefore, alternative processes are needed to valorize BG and other fatty acid-based feeds, including the FFA waste streams of the biodiesel industry.

The catalytic deoxygenation of FOG to fuel-like hydrocarbons offers advantages over biodiesel synthesis in terms of both feedstock flexibility and fuel quality. Moreover, deoxygenation via decarboxylation/decarbonylation $\left(\mathrm{deCO}_{\mathrm{x}}\right)$ as opposed to via hydrodeoxygenation (HDO) avoids the need for the high pressures of hydrogen and problematic sulfided catalysts required for $\operatorname{HDO}[9,10]$. Unfortunately, most deCO ${ }_{x}$ investigations to date employ model compounds in lieu of realistic feedstocks and very few studies use oleaginous waste streams as opposed to edible oils from terrestrial plants. Admittedly, the catalytic deoxygenation of some FOG waste streams to fuel-like hydrocarbons has been reported [11-14], although mostly over noble metal catalysts whose cost can be industrially prohibitive. Albeit the use of an inexpensive Ni-Cu catalyst to deoxygenate YG was demonstrated with near quantitative yields of fuel-like hydrocarbons [13], the YG was $>85 \%$ triglycerides. In fact, most realistic feeds employed in deoxygenation studies are mostly triglycerides, which is significant since carboxylic acids are less active towards deoxygenation than esters [15]. This is concerning since the majority of waste streams in general-and BG in particular-predominately consist of fatty acids. Therefore, catalysts considered for this process must be able to convert FFA feeds if they are to avoid the feed-related limitations of biodiesel production. Another complication of waste streams is the high degree of unsaturation that can exist. Relative to saturated feeds, unsaturated feeds typically yield more undesirable cracking products [16] and decrease catalyst activity through the adsorption and reaction of carbon-carbon double bonds [14]. Thus, catalyst development must take into account all these considerations.

There are a few reports on the use BG as feedstock in the production of renewable fuels including biodiesel [17], albeit the oxygen content of this fuel limits its ability to function as a universal drop-in replacement for fossil fuels. Alternatively, Sari et al. reported the deoxygenation of BG to fuel-like hydrocarbons. However, these authors employed a Pd/C catalyst comprising a noble metal and a support that precludes the catalyst from being easily regenerated upon deactivation [14]. Therefore, investigating the ability of the inexpensive oxide-supported $\mathrm{Ni}-\mathrm{Cu}$ catalyst developed in previous studies [13,18-20] to convert realistic FFA feeds under industrially relevant conditions is necessary if this technology is to become a commercially viable option for fuel production [10]. In this study, realistic fatty acid feeds as well as an industrially relevant set of reaction conditions were employed. To the best of the authors' knowledge, this represents the first report in which non-sulfided Ni catalysts have been tested under the aforementioned conditions and allowed to reach steady state, as well as the first assessment of catalyst stability and amenability to online regeneration.

\section{Results and Discussion}

\subsection{Catalytic Deoxygenation of An Industrial FFA Waste Stream at Different Temperatures}

Detailed characterization of the $20 \% \mathrm{Ni}-5 \% \mathrm{Cu} / \mathrm{Al}_{2} \mathrm{O}_{3}$ catalyst employed has been published previously $[13,18]$. The composition of the FFA feed obtained by steam stripping a biodiesel feedstock-as determined by simulated distillation GC-MS—is shown in Appendix A within Table A1. The feed is mostly fatty acids $(96.2 \%)$ and fatty acid esters $(2.3 \%)$, the most abundant fatty acids being 
oleic, palmitic, and stearic acids (ca. 63.5, 21.2 and 9.0\%, respectively). This feed was upgraded over $20 \% \mathrm{Ni}-5 \% \mathrm{Cu} / \mathrm{Al}_{2} \mathrm{O}_{3}$ in a fixed bed reactor using a WHSV of $1 \mathrm{~h}^{-1}$ and reaction temperatures ranging from 275 to $375{ }^{\circ} \mathrm{C}$. The results of simulated distillation GC-MS analysis of the liquid products from each hour of time on stream are shown in Figure 1 and in Appendix A (Tables A2-A4). Parenthetically, while all reaction parameters used to produce Figures 1-5 can be found in Section 3.4, the label “Heavier (C21-35)" may include oxygenates per Tables A2-A9 and the discussion below.

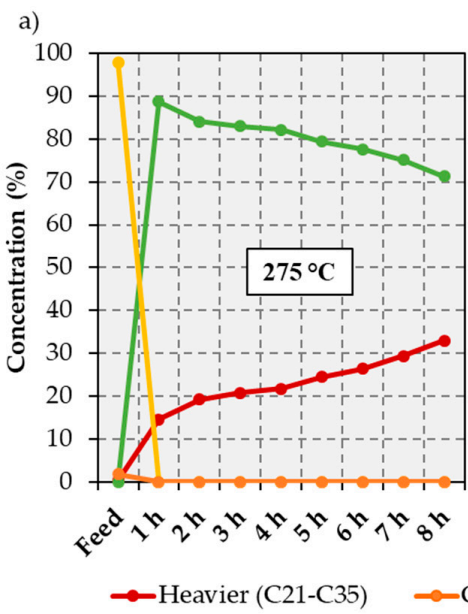

b)
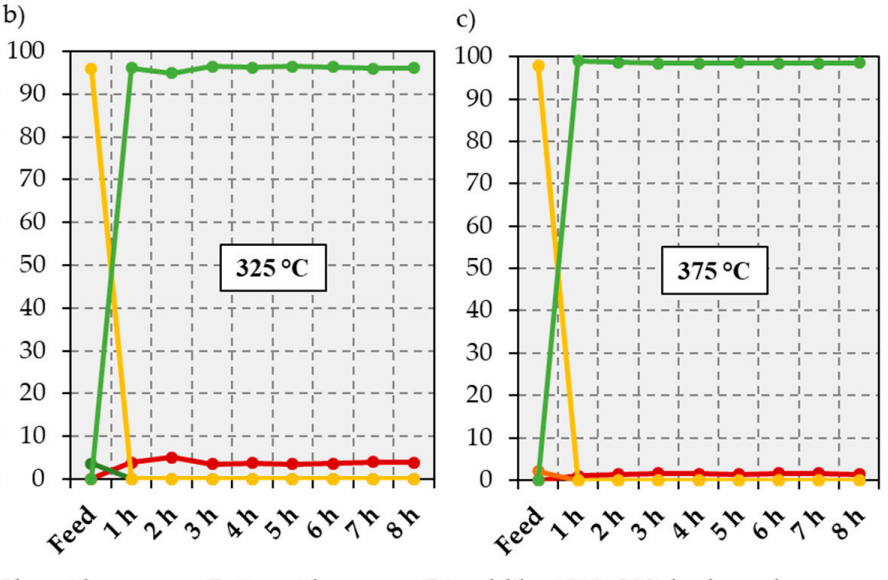

Figure 1. GC-MS analysis of liquid products in the catalytic upgrading of an FFA feed ( $25 \mathrm{wt} \%$ in C12) over $20 \% \mathrm{Ni}-5 \% \mathrm{Cu} / \mathrm{Al}_{2} \mathrm{O}_{3}$ at (a) 275 ; (b) 325 ; and (c) $375{ }^{\circ} \mathrm{C}$ (WHSV $=1.0 \mathrm{~h}^{-1}$ under $100 \% \mathrm{H}_{2}$ ).

At $275{ }^{\circ} \mathrm{C}$ the yield of diesel-like hydrocarbons (C10-C20) decreased from $88.8 \%$ at $1 \mathrm{~h}$ to $71.3 \%$ at $8 \mathrm{~h}$ on stream, while the selectivity to heavier products (C21-C35) progressively increased over the same time period. The heavy products, listed in Table A2, are mainly long chain esters that are formed when alcohol intermediates undergo esterification with fatty acids on the catalyst surface [21]. These side reaction products are less prominent at high reaction temperatures, as evinced by the lack of any oxygenates (heavy or otherwise) at $375{ }^{\circ} \mathrm{C}$, albeit the small amount of heavier (C21-C35) hydrocarbons formed at this temperature likely stems from the direct decarboxylation of long chain ester intermediates [21]. Alternatively, these esters can undergo hydrogenolysis to form alcohols and aldehydes, while the former can also be dehydrogenated to the latter as these two products have been shown to exist in equilibrium under hydrogen-rich conditions [21]. In turn, aldehydes can undergo decarbonylation to form diesel-like hydrocarbons. At $325^{\circ} \mathrm{C}$ the yield of diesel-like hydrocarbons is $\geq 95 \%$ irrespective of time on stream. Notably, near complete deoxygenation occurs at this temperature, with the highest amount of oxygenates (accumulated during the last hour of the experiment) totaling only $0.2 \%$ of the liquid products. Heavy products are still formed, but in significantly lower quantities than at $275{ }^{\circ} \mathrm{C}$. Complete deoxygenation occurs at all reaction times sampled when the reaction temperature is increased to $375{ }^{\circ} \mathrm{C}$, the selectivity to diesel-like hydrocarbons being $\geq 98 \%$ irrespective of time on stream. The increase in selectivity to diesel-like hydrocarbons as the reaction temperature increases is most likely due to: 1 ) the cracking of the long chain hydrocarbons ( $\geq$ C20) observed at lower reaction temperatures; and 2) direct deoxygenation of the fatty acids without formation of long chain ester intermediates.

\subsection{Catalytic Deoxygenation of Brown Grease at Different Temperatures}

The GC-MS analysis of the lipids extracted from the BG feed is also displayed in Appendix A within Table A1. The composition is similar to the industrial FFA waste stream above, the extracted lipids being mainly fatty acids (97.3\%) the most abundant of which are oleic, palmitic, and stearic acids (ca. $64.5,20.4$, and $8.7 \%$, respectively). In addition, the BG contains $2.66 \%$ glycerides (mostly diolein), signifying that the feed predominately consists of unsaturated lipids. Notably, this composition is 
comparable to other BG samples described in the literature $[14,22,23]$, which confirms that the simple extraction method employed (see Section 3.3) was effective in affording lipids representative of those contained in BG. The lipid concentration for these experiments was increased from that used in the FFA upgrading runs discussed in Section 2.1 above to $50 \mathrm{wt} \%$ lipids in dodecane, while the WHSV was kept at $1 \mathrm{~h}^{-1}$. This allowed an evaluation of the effect of feed concentration on the deoxygenation of free fatty acid-based feeds. In turn, the most promising reaction temperatures identified through the FFA upgrading runs-namely, 325 and $375{ }^{\circ} \mathrm{C}$-were investigated to assess the effect of temperature on the deoxygenation of BG lipids. The simulated distillation GC-MS analyses of the liquid products obtained during each hour are summarized in Figure 2 and in Appendix A (Tables A5 and A6), while the incondensable gaseous products are provided as Supplementary Material (Figure S1).

a)

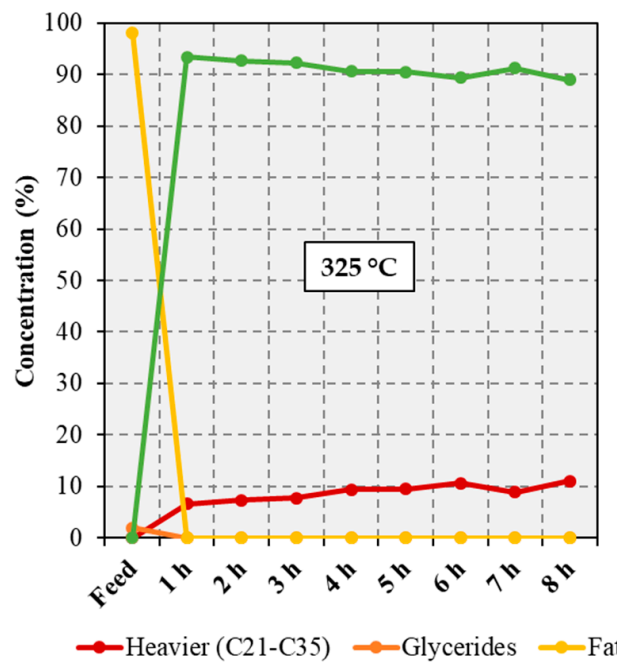

b)

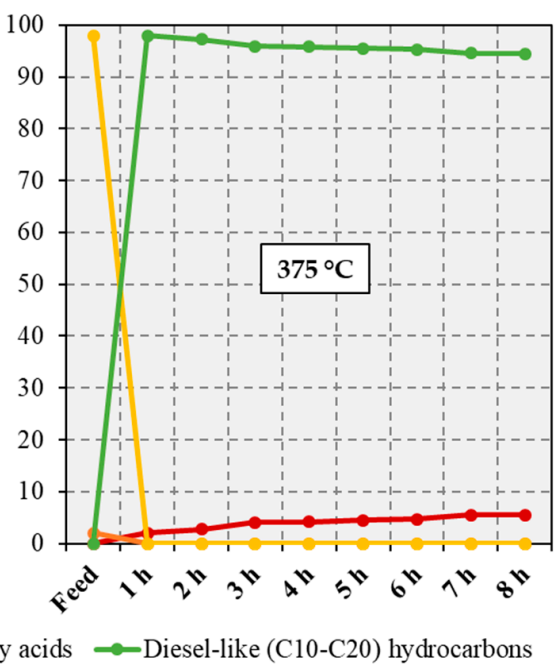

Figure 2. GC-MS analysis of the liquid products in the catalytic upgrading of a BG lipid feed (50 $\mathrm{wt} \%$ in C12) over $20 \% \mathrm{Ni}-5 \% \mathrm{Cu} / \mathrm{Al}_{2} \mathrm{O}_{3}$ at (a) 325 ; and (b) $375^{\circ} \mathrm{C}$ (WHSV $=1.0 \mathrm{~h}^{-1}$ under $100 \% \mathrm{H}_{2}$ ).

Quantitative conversion of the BG lipids was achieved regardless of the reaction temperature employed. However, the deoxygenation of the BG lipids at $325^{\circ} \mathrm{C}$ yields more than double the amount of heavy products that was obtained in the free fatty acid experiments at the same temperature, reaching $11 \%$ of the total liquid products at $8 \mathrm{~h}$ on stream. Other authors have seen an increase in heavy products as the feed concentration increases and suggested that this stems from an increase in the amount of fatty acids present on the catalyst surface [14]. The rise in fatty acid concentration increases the possibility of esterification reactions with the alcohol intermediates, forming long chain esters that can undergo direct decarboxylation to yield heavy hydrocarbons. However, the esters observed in the FFA upgrading experiments were not detected in the BG upgrading experiments, suggesting that rapid decarboxylation occurs upon formation of the ester intermediates. Remarkably, $>94 \%$ of the liquid products obtained during the deoxygenation of the BG lipids at $375^{\circ} \mathrm{C}$ are diesel-like hydrocarbons at all reaction times sampled. Parenthetically, at $375^{\circ} \mathrm{C}$ there were a number of liquid products-from $9.74 \%$ at $\mathrm{t}=1 \mathrm{~h}$ to $7.62 \%$ at $\mathrm{t}=8 \mathrm{~h}$ (see Appendix A Table A6)-deemed to be hydrocarbons by the GC-MS, although their specific identity could not be determined. Nevertheless, according to the simulated distillation GC of these unidentifiable products, they all boil within the diesel range $\left(180-350{ }^{\circ} \mathrm{C}\right)$. The heavy product formation also decreased at the higher reaction temperature, the total amount obtained being $<6 \%$ of the liquid products irrespective of time on stream. This is consistent with higher temperatures favoring the occurrence of cracking reactions, which is also indicated by the higher amount of gaseous C1-C4 products obtained at $375{ }^{\circ} \mathrm{C}$ (see Supplementary Material). Nevertheless, only a relatively small amount of the carbon in the feed becomes $\mathrm{C} 1-\mathrm{C} 4$ gaseous 
products. Indeed, at $325{ }^{\circ} \mathrm{C}$ only $3.5 \mathrm{~mol} \%$ of the carbon in the BG feed is converted to these gaseous products, this value reaching $6.1 \mathrm{~mol} \%$ when the reaction temperature is increased to $375^{\circ} \mathrm{C}$.

\subsection{Catalytic Deoxygenation of Brown Grease at Different $\mathrm{H}_{2}$ Partial Pressures}

The presence of $\mathrm{H}_{2}$ in the reaction atmosphere has been shown to improve catalyst performance during the deCO $\mathrm{O}_{x}$ of lipids even if $\mathrm{H}_{2}$ is not directly involved in the deoxygenation reaction [24-26]. Interestingly, some authors have also shown that supported Pd catalysts perform better under lower $\mathrm{H}_{2}$ partial pressure conditions than under pure $\mathrm{H}_{2}$ atmospheres [27], and the same effect has been reported for some Ni catalysts [26]. Therefore, it is instructive to investigate the effect of $\mathrm{H}_{2}$ partial pressure on the deoxygenation of waste fatty acid-based feeds. To this end, the deoxygenation of BG was conducted under a reaction atmosphere of $20 \% \mathrm{H}_{2} / \mathrm{Ar}$ at $375^{\circ} \mathrm{C}$, the GC-MS analysis of the liquid products being shown in Figure 3 and in Appendix A (Table A7), while the incondensable gaseous products are also shown in Figure 3. Note that the part of the y-axis not shown in Figures 3 and 5 consists entirely of the reaction atmosphere, i.e., either $\mathrm{H}_{2}$ or a mixture of $\mathrm{H}_{2}$ and Ar.
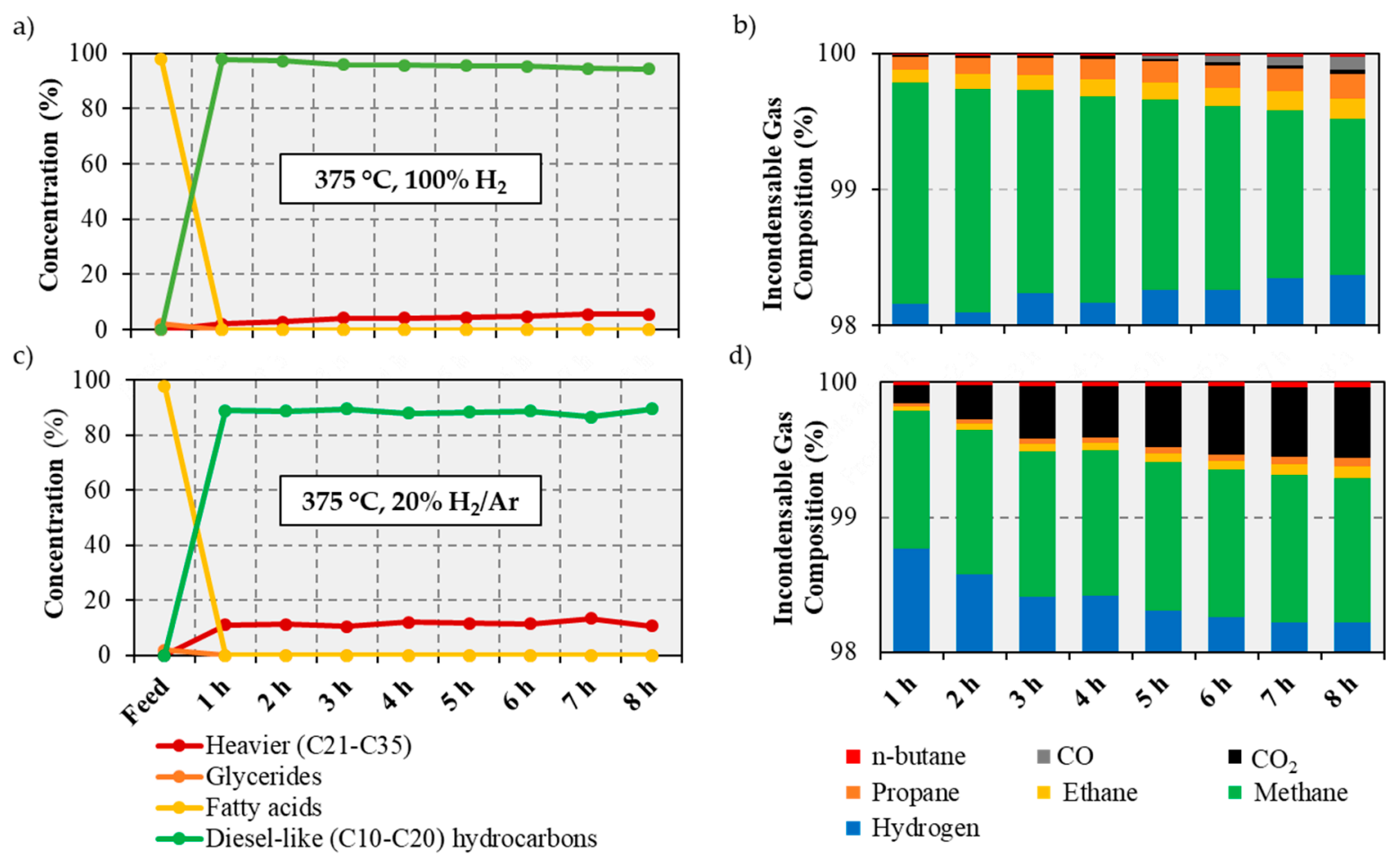

d)

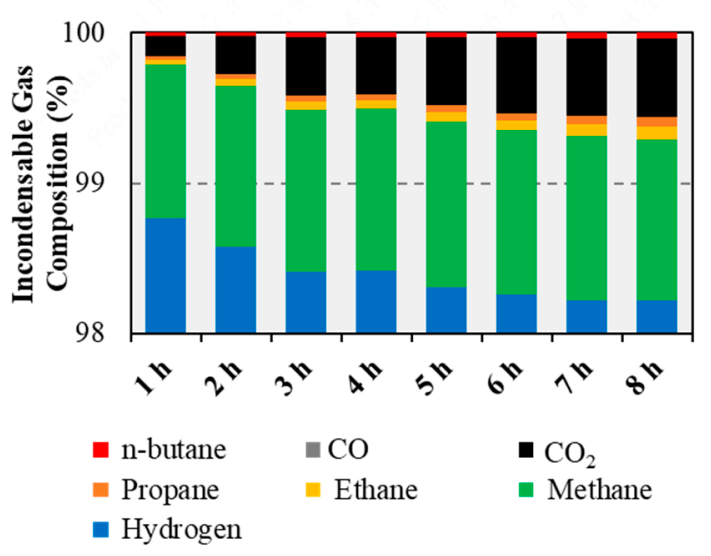

Figure 3. GC-MS of the liquid products—(a) and (c)—and GC analysis—(b) and (d)—of the gaseous products from the deoxygenation of $\mathrm{BG}$ lipids at different $\mathrm{H}_{2}$ partial pressures.

Under $20 \% \mathrm{H}_{2}$, the $20 \% \mathrm{Ni}-5 \% \mathrm{Cu} / \mathrm{Al}_{2} \mathrm{O}_{3}$ catalyst quantitatively converts the $\mathrm{BG}$ feed, no trace of starting material being observed at any reaction time sampled (see Figure 3c). However, the amount of diesel-like hydrocarbons in the reaction products decreases to $86-89 \%$ of the total liquid products relative to the $94-98 \%$ values observed when the reaction is performed under pure $\mathrm{H}_{2}$ (see Figure 3a). Additionally, the amount of heavy products increases when the reaction is performed under reduced $\mathrm{H}_{2}$ partial pressure, albeit it is worth noting that only a relatively small amount (an average of $14.8 \%$ ) of the total heavy products collected are long chain esters. The increase in the amount of long chain hydrocarbons suggests that after the formation of esters, the lower $\mathrm{H}_{2}$ partial pressure favors their direct decarboxylation, as opposed to their hydrogenolysis to afford alcohols and aldehydes [21]. Interestingly, while there is only a small decrease in the yield of diesel-like products, the gaseous products show a noticeable decrease in methane formation when the reaction is performed under reduced $\mathrm{H}_{2}$ partial pressure (see Figure 3b,d). Indeed, while the amount of $\mathrm{CO}$ or $\mathrm{CO}_{2}$ present in the 
gaseous products obtained using pure $\mathrm{H}_{2}$ is negligible and methane represents the vast majority of the gaseous products, the gas products contain considerably more $\mathrm{CO}_{2}$ and less methane when the reaction is run under $20 \% \mathrm{H}_{2}$. Therefore, under reduced $\mathrm{H}_{2}$ partial pressures, methanation of $\mathrm{CO}_{x}$ is disfavored and does not proceed to completion. Instead, the methane formed at lower $\mathrm{H}_{2}$ partial pressures is likely formed from the fatty acids alkyl chains via the end-chain cracking mechanism described in a recent contribution [13]. As with other experiments, only a relatively small amount of the carbon in the BG feed becomes $\mathrm{C} 1-\mathrm{C} 4$ gaseous products, this value being $5.8 \mathrm{~mol} \%$ for the experiment performed under reduced $\mathrm{H}_{2}$ partial pressure.

\subsection{Catalyst Deactivation and Online Regeneration}

Tellingly, the composition of the gas products is still changing not only at the end of the reactions discussed in Section 2.3, but also at the end of previously reported YG and hemp seed oil upgrading experiments [13], all of which lasted eight hours. Therefore, it appears that eight hours do not constitute sufficient time for the attainment of steady state. Obviously, this also hinders an assessment of whether significant catalyst deactivation occurs when upgrading a realistic feed under these conditions. Therefore, the most promising conditions evaluated in this study, i.e., $375^{\circ} \mathrm{C}$ and a pure $\mathrm{H}_{2}$ atmosphere, were employed in a run in which the deoxygenation reaction time was extended to $100 \mathrm{~h}$ on stream. After this (first) $100 \mathrm{~h}$ cycle, the catalyst was regenerated in situ by washing, drying, calcining (in air), and re-reducing the catalyst (under flowing $\mathrm{H}_{2}$ ). Catalyst calcination was performed for $5 \mathrm{~h}$ at $450{ }^{\circ} \mathrm{C}$, which is both the top temperature rating of the furnace employed and a temperature at which the majority of the carbonaceous deposits can be eliminated according to the results of thermogravimetric analysis (see Section 2.5 and Figure 7). Results from the analysis of representative liquid samples (recovered at $24 \mathrm{~h}$ intervals) are shown in Figure 4 and in Appendix A (Tables A8 and A9), the analysis of the gaseous products being shown in Figure 5. It should be noted that the results shown correspond to products recovered in a single hour and not to products accumulated over a $24 \mathrm{~h}$ period, such that the catalyst performance can be assessed at the specified time intervals with a "time resolution" equal to one hour.

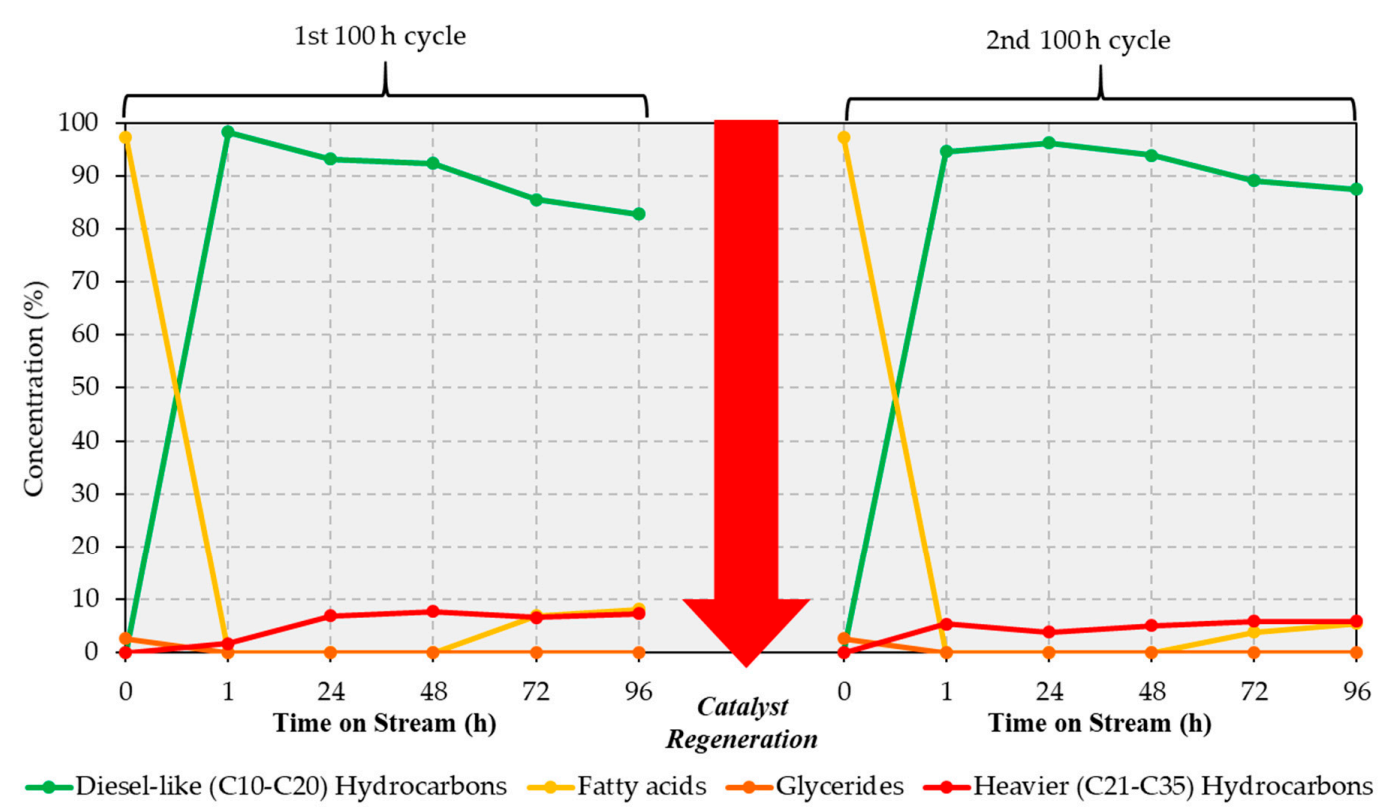

Figure 4. GC-MS analysis of select liquid samples in the deoxygenation of BG lipids for $100 \mathrm{~h}$ on stream at $375{ }^{\circ} \mathrm{C}$ and 40 bar of $100 \% \mathrm{H}_{2}$ before and after in situ catalyst regeneration.

During the first $100 \mathrm{~h}$ run, quantitative conversion of the BG lipids is achieved during the initial $48 \mathrm{~h}$. After that, the amount of fatty acids in the products begins to increase, reaching a total of $8.1 \%$ of the total liquid products collected at the end of the first $100 \mathrm{~h}$ cycle. The yield of diesel-like 
hydrocarbons is $>92 \%$ of the liquid products for the first $48 \mathrm{~h}$ on stream, this value decreasing to $82.8 \%$ after $96 \mathrm{~h}$ on stream. Notably, catalyst performance improves after the catalyst is regenerated in situ, the yield of diesel-like hydrocarbons being $~ 90 \%$ or greater for $72 \mathrm{~h}$ on stream during the second $100 \mathrm{~h}$ cycle. Interestingly, improvements in performance following catalyst regeneration have been reported for other Ni-based formulations, which was attributed to an increase in the number of strong basic sites during the treatment of the spent catalyst in hot air [26]. A closer look at the individual components of the liquid products (listed in Tables A8 and A9) provides valuable information vis-à-vis changes in selectivity that take place as the reaction progresses and/or after catalyst regeneration. Indeed, while the vast majority of the feed (93.6\%) comprised C18 and C16 fatty acids-73.2 and $20.4 \%$ of the feedstock, respectively - the most abundant products are $\mathrm{C} 17$ and $\mathrm{C} 15$ hydrocarbons, suggesting that the reaction proceeds mainly via deCO $\mathrm{x}_{\mathrm{x}}$ as opposed to HDO. Nevertheless, $\mathrm{C} 18$ and C16 hydrocarbons are also produced in significant amounts, which indicates that HDO also occurs to some extent. Additionally, of note is the trend followed by lighter diesel-like hydrocarbons (C10-C14), whose abundance in the product mixtures tends to decrease with time on stream and after regeneration (see Tables A8 and A9). This indicates that cracking reactions progressively become less prevalent and implies that surface sites responsible for cracking deactivate gradually and irreversibly. This is in line with the evolution of the incondensable gas products with time on stream, which also provides valuable insights regarding the changes in selectivity observed as the reaction advances and after catalyst regeneration (see Figure 5).

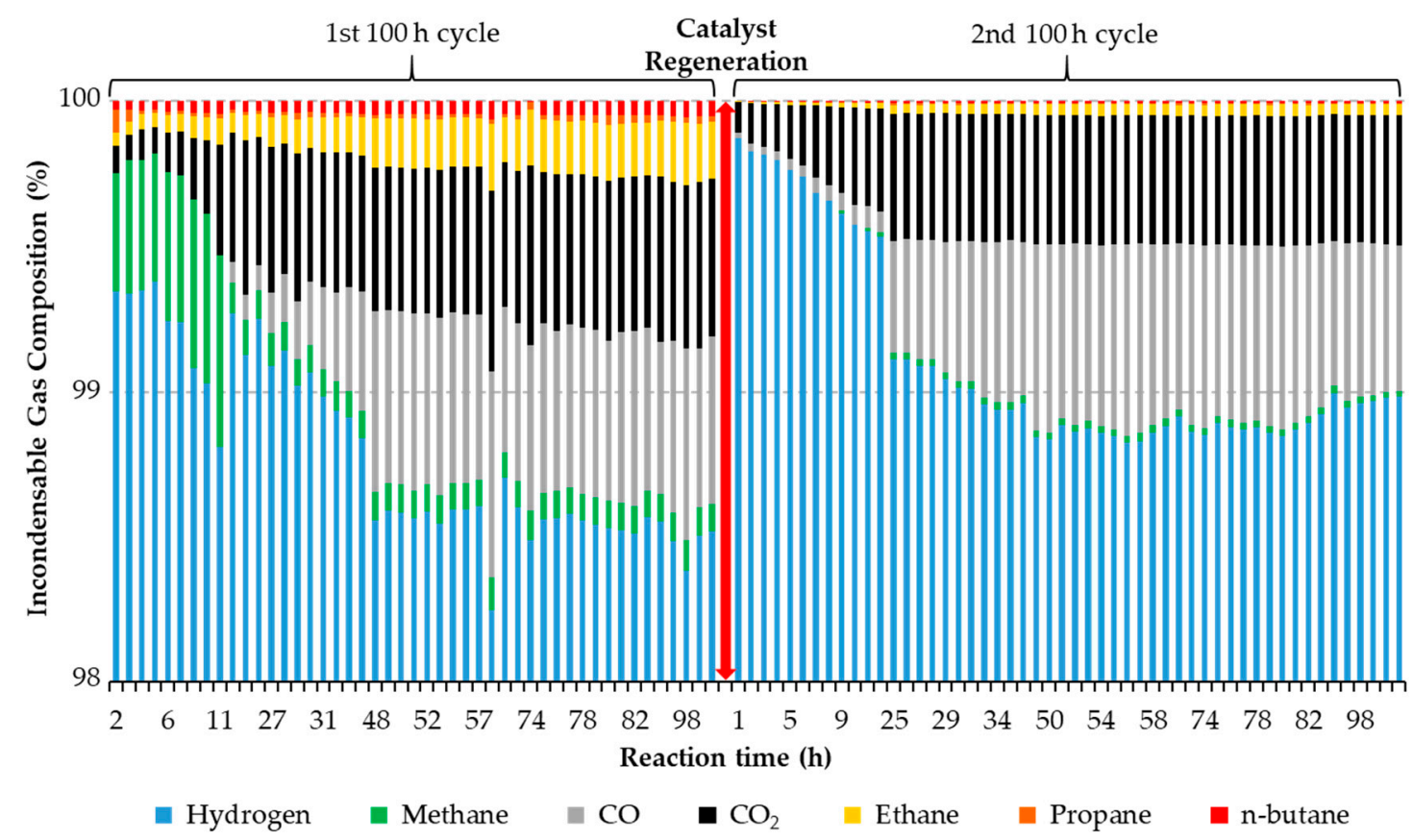

Figure 5. GC analysis of select gas samples in the deoxygenation of BG lipids for $100 \mathrm{~h}$ on stream at $375{ }^{\circ} \mathrm{C}$ and 40 bar of $100 \% \mathrm{H}_{2}$ before and after in situ catalyst regeneration.

First, the difference in the amount of light (C1-C4 alkanes) observed before and after regeneration confirms the irreversible deactivation of cracking sites. Indeed, these gases result from the shortening of alkyl chains via terminal carbon loss (-C1) and internal chain cracking (-C2, $-\mathrm{C} 3$, and $-\mathrm{C} 4)$, both of which also lead to the formation of $\mathrm{C} 10-\mathrm{C} 14$ fuel-like hydrocarbons [13]. However, the fact that both light (C10-C14) fuel-like hydrocarbons and methane tend to decrease with time on stream prior to remaining fairly constant-while $\mathrm{C} 2-\mathrm{C} 4$ hydrocarbons follow the opposite trend-suggests that chain shortening occurs mainly through the removal of terminal carbons, which is in line with the conclusions of a recent contribution [13]. Moreover, changes in the amounts of $\mathrm{CO}_{\mathrm{x}}$ and methane-which progressively increase and decrease, respectively (Figure 5, left)—may also suggest 
that sites responsible for methanation are gradually and irreversibly poisoned as the reaction progresses. This represents a noteworthy result, since hydrogen consumption should correspondingly decrease with time on stream without sacrificing significant deoxygenation activity. Lastly, it is worth noting the induction period (observed at the beginning of both cycles in Figure 5 but also in Figure 3d) in which the concentration of $\mathrm{CO}_{\mathrm{x}}$ gradually increases with time on stream prior to becoming relatively constant at steady state. Given that methane formation is negligible during the second $100 \mathrm{~h}$ cycle (right of Figure 5), the low concentration of $\mathrm{CO}_{\mathrm{x}}$ during this induction period cannot be assigned to $\mathrm{CO}_{x}$ methanation. Instead, this can be attributed to the accumulation of $\mathrm{CO}_{x}$ on the catalyst surface, which has to become saturated before $\mathrm{CO}_{2}$ and $\mathrm{CO}$ can break through. Indeed, a previous contribution has shown that $\mathrm{CO}_{2}$ accumulates on the surface of $20 \% \mathrm{Ni}-5 \% \mathrm{Cu} / \mathrm{Al}_{2} \mathrm{O}_{3}$ as alumina-bound carbonates [13]. Based on the results in Figure 5-and ignoring the effects of potentially confounding reactions (including methanation, water gas shift and the Boudouard reaction)-it seems that deoxygenation proceeds fairly equally via decarboxylation $\left(-\mathrm{CO}_{2}\right)$ and decarbonylation $(-\mathrm{CO})$ once the system reaches steady state. Although—as with other experiments—only a relatively small amount of the carbon in the feed becomes $\mathrm{C} 1-\mathrm{C} 4$ gaseous products, the values obtained for this experiment are particularly informative, since this is the only experiment in which steady state was attained before and after catalyst regeneration. Tellingly, in the first $100 \mathrm{~h}$ cycle, the fraction of carbon in the feed converted to C1-C4 gaseous products starts at $\sim 2 \mathrm{~mol} \%$ before reaching a maximum of $\sim 7 \mathrm{~mol} \%$ at 11 $\mathrm{h}$ on stream, an increase that can be ascribed to the initial accumulation of $\mathrm{CO}_{2}$ on the catalyst surface mentioned above. Subsequently, this value stabilizes between $\sim 2.5$ and $\sim 4.9 \mathrm{~mol} \%$ for the remainder of the first $100 \mathrm{~h}$ cycle. During the second $100 \mathrm{~h}$ cycle (after catalyst regeneration), the fraction of carbon in the feed converted to $\mathrm{C} 1-\mathrm{C} 4$ gaseous products starts at $\sim 0.4 \mathrm{~mol} \%$ before stabilizing (at around $24 \mathrm{~h}$ on stream and for the remainder of the experiment) between $\sim 2.6$ and $\sim 3.6 \mathrm{~mol} \%$. This is consistent with both the initial accumulation of $\mathrm{CO}_{2}$ on the regenerated catalyst surface and the lower cracking activity observed after catalyst regeneration.

\subsection{Catalyst Characterization}

Although the characterization of the $20 \% \mathrm{Ni}-5 \% \mathrm{Cu} / \mathrm{Al}_{2} \mathrm{O}_{3}$ catalyst used in this contribution has been described previously [18], additional characterization work was performed in this study, including an investigation of room temperature $\mathrm{CO}$ adsorption on the fresh and spent catalyst via diffuse reflectance infrared Fourier transform spectroscopy (DRIFTS), the resulting spectra being shown in Figure 6.

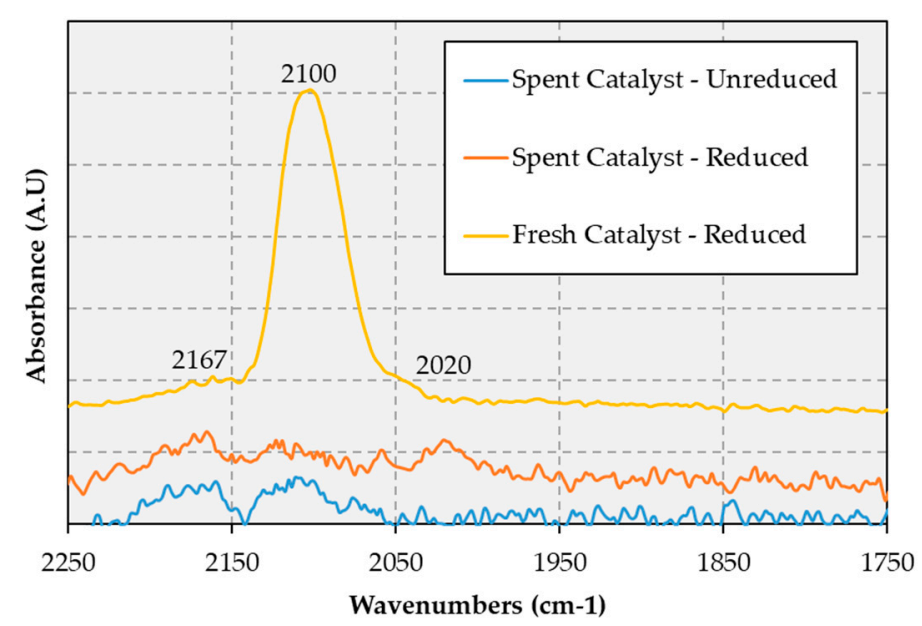

Figure 6. DRIFTS spectra of the fresh catalyst after reduction, the spent catalyst, and the spent catalyst after reduction. 
$\mathrm{CO}$ adsorption on the reduced fresh catalyst produced a strong absorbance peak at $2100 \mathrm{~cm}^{-1}$. Since $\mathrm{CO}$ adsorption on the spent catalyst did not afford this peak, the spent catalyst was reduced in situ (i.e., inside the DRIFTS cell) to counter any oxidation that may have occurred when the catalyst was exposed to air while being transferred from the reactor to the DRIFTS cell. The reduced spent catalyst also lacked the $\mathrm{CO}$ adsorption peak, which indicates that the surface active sites that readily adsorb $\mathrm{CO}$ on the reduced fresh catalysts are irreversibly poisoned-or otherwise eliminated-under the reaction conditions employed. This could explain the reduced methane formation observed during the second $100 \mathrm{~h}$ cycle, as less $\mathrm{CO}$ adsorbs on the catalyst surface. In fact, the $\mathrm{C} 1$ gaseous products observed during the second $100 \mathrm{~h}$ cycle are almost entirely $\mathrm{CO}$ and $\mathrm{CO}_{2}$, which is consistent with decreased methanation. Given than in previous work on $20 \% \mathrm{Ni}-5 \% \mathrm{Cu} / \mathrm{Al}_{2} \mathrm{O}_{3}$ and $4.7 \% \mathrm{Cu} / \mathrm{Al}_{2} \mathrm{O}_{3} \mathrm{CO}$ DRIFTS bands at 2121 and $2115 \mathrm{~cm}^{-1}$ were assigned to $\mathrm{CO}$ adsorbed on $\mathrm{Cu}$ sites $[18,28]$, it is possible that during reaction these sites are made inaccessible by the deposition of carbonaceous material on the surface of metal particles (vide infra and see Figure A1 in Appendix B). However, another possibility is that in the course of the reaction these sites tend to disappear via sintering and/or alloying with $\mathrm{Ni}$ (see Figure 8 and Figure A2 in Appendix B). Since previous CO DRIFTS measurements on $20 \% \mathrm{Ni}-5 \% \mathrm{Cu} / \mathrm{Al}_{2} \mathrm{O}_{3}$ have also confirmed an electronic interaction between $\mathrm{Cu}$ and $\mathrm{Ni}$ [18], it can be argued that these changes would also have an electronic effect on surface $\mathrm{Ni}$, which offers one potential explanation for the absence of a band at $2050 \mathrm{~cm}^{-1}$ attributable to CO adsorbed on Ni sites [29]. Interestingly, other authors have observed improved catalytic performance when the $\mathrm{CO}$ binding energy to $\mathrm{Ni}$ is lowered, as this causes active sites to be freed up more readily during $\mathrm{deCO}_{\mathrm{x}}$ thereby resulting in enhanced activity [30]. In fact, the CO produced via decarbonylation is a known catalyst poison-as well as a coke precursor (vide infra)—and, thus, a lower amount and/or a reduced residency time of $\mathrm{CO}$ on the catalyst surface should benefit deCO $\mathrm{O}_{x}$ activity [31].

The conclusions garnered from DRIFTS measurements are reinforced by the results of $x$-ray photoelectron spectroscopy (XPS) analyses performed on both the fresh and spent catalysts (see Figure A3 in Appendix B). Indeed, while the spent catalyst displays features indicative of deactivation via coking and fouling-i.e., increased intensity of carbon peaks (not shown) and lower intensity of peaks associated with metals-a shift in both $\mathrm{Ni}$ and $\mathrm{Cu}$ peak maxima consistent with surface reduction to form metallic phases and a Ni-Cu alloy [32,33] is also observed. While the extent of alloying is difficult to determine quantitatively in the absence of density of state measurements, qualitative examination of the peak positions indicate a shift of the $\mathrm{Cu} 2 \mathrm{p}_{3 / 2}$ binding energy to $\sim 0.2 \mathrm{eV}$ higher than that expected for copper metal, consistent with significant $\mathrm{Ni}-\mathrm{Cu}$ alloying [34,35]. Integrating the respective $\mathrm{Ni}$ and $\mathrm{Cu}$ peaks after correcting for background and elemental sensitivity also shows evidence of $\mathrm{Cu}$ enrichment on the surface of the spent catalyst, with the surface $\mathrm{Ni} / \mathrm{Cu}$ atomic ratio decreasing from $5.55 \mathrm{Ni}$ atoms per $\mathrm{Cu}$ atom to $4.14 \mathrm{Ni}$ atoms per $\mathrm{Cu}$ atom after $200 \mathrm{~h}$ on stream [36]. Taken together, the CO-DRIFTS and the XPS data provide compelling evidence that both surface enrichment of copper and alloying of $\mathrm{Ni}$ with $\mathrm{Cu}$ have occurred, with other authors reporting depth profiling of similar species evincing near total coverage of metal particles by $\mathrm{Cu}$ despite XPS integrals consistent with the bulk composition [36].

The thermogravimetric analysis (TGA) results in Figure 7 show that the total mass loss displayed by the spent catalyst is 9.5 and $5.1 \%$ after the first and second $100 \mathrm{~h}$ cycle, respectively. This indicates that less coke forms during the second $100 \mathrm{~h}$ cycle, i.e., after the catalyst regeneration step. Catalytic cracking of the feed is known to exacerbate catalyst deactivation via coking and to be particularly problematic for Ni-based catalysts [37]. As mentioned above, light hydrocarbons such as ethane, propane and butane are observed in greater abundance in the gaseous products evolved during the first $100 \mathrm{~h}$ cycle relative to the amount observed during the second $100 \mathrm{~h}$ cycle. This is consistent with the notion that the increased coking observed during the first $100 \mathrm{~h}$ stems from a higher cracking activity. Thus, sites responsible for cracking reactions appear to become irreversibly deactivated during the first $100 \mathrm{~h}$ cycle. Additionally, since adsorbed CO can also contribute to coking 
via the Boudouard reaction, the lower $\mathrm{CO}$ adsorption discussed above could also explain the decrease in carbonaceous deposits formed on the catalyst surface during the second $100 \mathrm{~h}$ cycle.

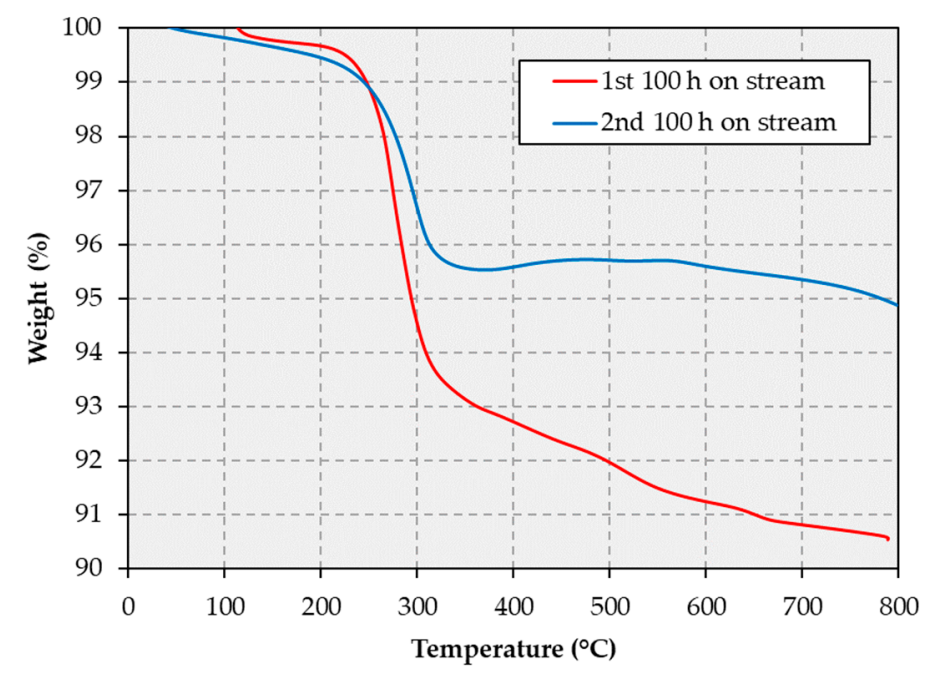

Figure 7. TGA (in air) of the dried spent catalyst from the deoxygenation of BG lipids at $375{ }^{\circ} \mathrm{C}$ and 40 bar of $100 \% \mathrm{H}_{2}$ after the first $100 \mathrm{~h}$ and the second $100 \mathrm{~h}$ on stream.

Important insights were also gained through the analysis of the fresh and spent (after the second $100 \mathrm{~h}$ on stream) catalyst via transmission electron microscopy-energy dispersive $\mathrm{X}$-ray spectroscopy (TEM-EDS). First, TEM results show that while the metal particle size distribution in the fresh catalysts is narrow and centers around $4 \mathrm{~nm}$ particles, the spent catalyst has a wider particle size distribution with a considerable number of particles larger than $10 \mathrm{~nm}$ and as large as $40 \mathrm{~nm}$ (see Figures $8 \mathrm{a}$ and A2 in Appendix B). The fact that large particles arise at the expense of smaller particles (see Figure 8a) suggests that sintering occurs via Ostwald ripening. TEM-EDS results show that the composition of metal particles in the fresh catalyst is very consistent and close to the composition of the bulk catalyst (particles of $80 \% \mathrm{Ni}-20 \% \mathrm{Cu}$ are expected for a $20 \% \mathrm{Ni}-5 \% \mathrm{Cu} / \mathrm{Al}_{2} \mathrm{O}_{3}$ formulation, atomic and weight percent being very close due to the similar atomic weight of $\mathrm{Ni}$ and $\mathrm{Cu}$ ), albeit a significant number of Ni-rich (85-95\% Ni) particles is also observed (see Figure $8 \mathrm{~b}$ ). However, the composition of metal particles in the spent catalyst is considerably different, as Cu-rich particles-from slightly enriched $(75 \% \mathrm{Ni}-25 \% \mathrm{Cu})$ to greatly enriched $(35 \% \mathrm{Ni}-65 \% \mathrm{Cu})$-arise at the expense of the Ni-rich particles in the fresh catalyst. In short, the TEM and TEM-EDS results in Figure 8 suggest that in the course of the experiment metal particles tend to both grow and become $\mathrm{Cu}$-rich. The latter is consistent with the results of elemental mapping included in Figure A2 in Appendix B, which also show that $\mathrm{Ni}$ and $\mathrm{Cu}$ are closely associated irrespective of the catalyst state (fresh or spent). Nevertheless, more detailed studies - which fall outside the scope of this contribution - are needed to more thoroughly ascertain the relationship between particle size and both surface and bulk composition. 
a)

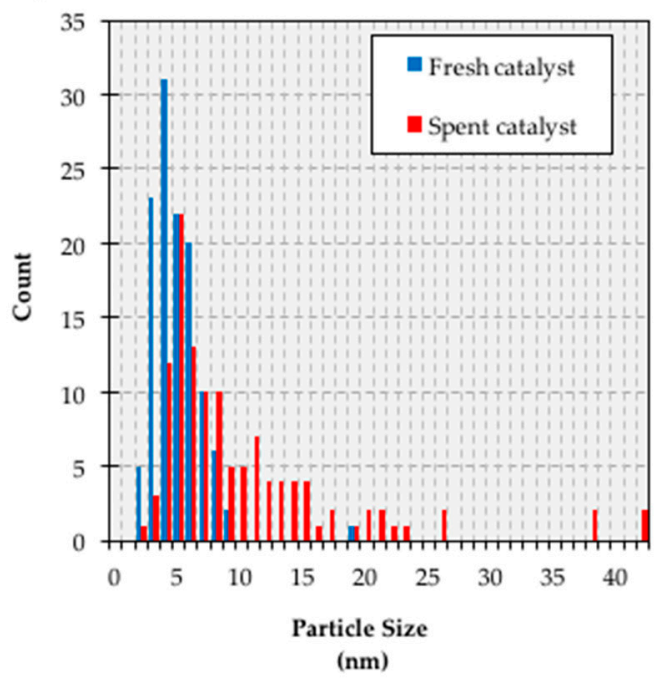

b)

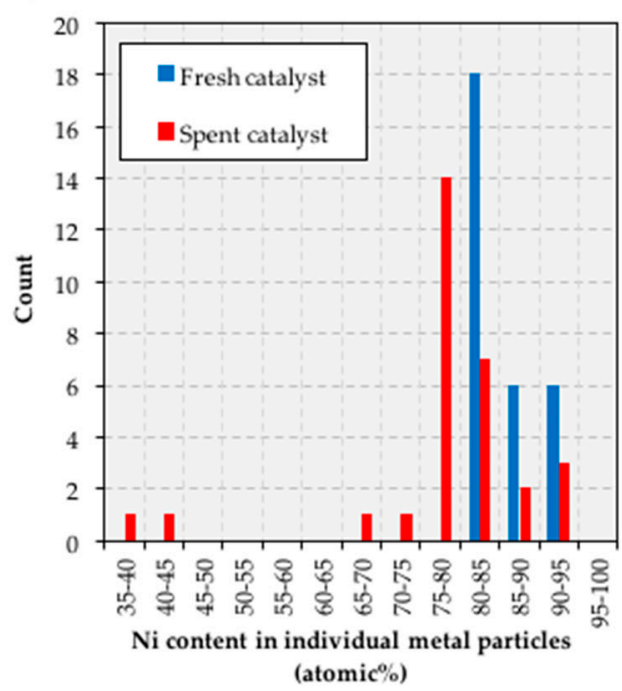

Figure 8. Particle size distribution (a) and metallic composition (b) histograms for the fresh and spent (after the second $100 \mathrm{~h}$ on stream) catalyst.

Finally, since it could be argued that the $\mathrm{Cu}$ enrichment of the catalyst can be attributed to the reaction between $\mathrm{CO}$ and $\mathrm{Ni}$ resulting in the formation of volatile $\mathrm{Ni}$ carbonyl and the concomitant loss of $\mathrm{Ni}$, the fresh and spent (after the second $100 \mathrm{~h}$ cycle) catalyst was analyzed by inductively-coupled plasma-atomic emission spectroscopy (ICP-AES). Tellingly, while the material loaded into the reactor (a 1:1 mixture of catalyst and $\mathrm{SiC}$ diluent) had a $\mathrm{Ni}$ and $\mathrm{Cu}$ content of 8.87 and $1.98 \%$, respectively, the corresponding values for the material recovered from the reactor (which also included $9.5 \%$ of coke deposits) were 7.39 and $1.62 \%$ (or 8.16 and $1.79 \%$ when corrected for coke). This corresponds to a $\mathrm{Ni} / \mathrm{Cu}$ ratio of $\sim 4.48$ and $\sim 4.56$ for the fresh and spent catalysts, respectively, which clearly indicates that the catalyst experiences no loss of $\mathrm{Ni}$. This is consistent with a report on the kinetics of nickel carbonyl formation [38]. Indeed, the authors of this report concluded that the highly exothermic reaction that forms nickel carbonyl reaches a maximum rate at $\sim 7{ }^{\circ} \mathrm{C}$, after which nickel carbonyl formation decreases to reach negligible levels by $150{ }^{\circ} \mathrm{C}$ irrespective of the pressures (partial $\mathrm{CO}, \mathrm{H}_{2}$, or total pressure) employed. In deoxygenation experiments, the catalyst would only be exposed to $\mathrm{CO}$ at the reaction temperature of $375^{\circ} \mathrm{C}$, i.e., well above the range in which nickel carbonyl would form to an appreciable degree per the reference above. These results further confirm both the robustness of the catalyst under reaction conditions and its industrial applicability.

\section{Materials and Methods}

\subsection{Catalyst Preparation}

Catalysts were prepared by excess wetness impregnation using $\mathrm{Ni}\left(\mathrm{NO}_{3}\right)_{2} \cdot 6 \mathrm{H}_{2} \mathrm{O}$ (Alfa Aesar, Haverhill, MA, USA) and $\mathrm{Cu}\left(\mathrm{NO}_{3}\right)_{2} \cdot 3 \mathrm{H}_{2} \mathrm{O}$ (Sigma Aldrich, St. Louis, MO, USA) as the metal precursors. Beads of $\gamma-\mathrm{Al}_{2} \mathrm{O}_{3}$ (Sasol, Johannesburg, South Africa; surface area of $216 \mathrm{~m}^{2} / \mathrm{g}$ ) were used as the support and were crushed to a particle size of $<150 \mu \mathrm{m}$ before the impregnation. The target metal loadings for the catalyst were $20 \mathrm{wt} \% \mathrm{Ni}$ and $5 \mathrm{wt} \% \mathrm{Cu}$. The impregnated catalyst was dried overnight at $60{ }^{\circ} \mathrm{C}$ under vacuum prior to calcination for $3 \mathrm{~h}$ at $500^{\circ} \mathrm{C}$ in static air. The catalyst and $\mathrm{SiC}$ catalyst diluent (Kramer Industries, Piscataway Township, NJ, USA) were sieved separately to a particle size between 150 and $300 \mu \mathrm{m}$ and stored in a vacuum oven at $60^{\circ} \mathrm{C}$ until use.

\subsection{Catalyst Characterization}

A small sample of the catalyst after the first $100 \mathrm{~h}$ on stream (in an experiment involving two $100 \mathrm{~h}$ cycles and an intermediate catalyst regeneration step) was subjected to TGA under flowing air 
$(50 \mathrm{~mL} / \mathrm{min}$ ) on a TA instruments (New Castle, DE, USA) Discovery Series thermogravimetric analyzer. The temperature was ramped from room temperature to $800^{\circ} \mathrm{C}$ at a rate of $10^{\circ} \mathrm{C} / \mathrm{min}$. The same TGA procedure was used on the spent catalyst after the second $100 \mathrm{~h}$ cycle. DRIFTS was performed on the fresh and the spent catalyst after CO adsorption using a Thermo Scientific (Waltham, MA, USA) Nicolette 6700 FTIR instrument equipped with a Harrick Scientific (Pleasantville, NY, USA) praying mantis DRIFTS cell. The catalysts were dried under flowing $\operatorname{Ar}(50 \mathrm{~mL} / \mathrm{min})$ at $200{ }^{\circ} \mathrm{C}$ for $2 \mathrm{~h}$ and allowed to cool to $25^{\circ} \mathrm{C}$. The catalyst sample was then subjected to flowing $1 \% \mathrm{CO} / \mathrm{Ar}(50 \mathrm{~mL} / \mathrm{min})$ at $25^{\circ} \mathrm{C}$ for $1 \mathrm{~h}$, followed by Ar purging to remove gas phase $\mathrm{CO}$ and weakly absorbed $\mathrm{CO}$ before the spectrum was collected. The sample was then heated to $200^{\circ} \mathrm{C}$ under flowing $\mathrm{Ar}(50 \mathrm{ml} / \mathrm{min})$ and complete CO desorption was monitored by a return of the DRIFTS signal to a previously established baseline. The gas flow was then switched to $10 \% \mathrm{H}_{2} / \mathrm{N}_{2}(50 \mathrm{~mL} / \mathrm{min})$ as the temperature was increased to $400{ }^{\circ} \mathrm{C}$ and held for $1 \mathrm{~h}$. The catalyst was then cooled to $25^{\circ} \mathrm{C}$ under flowing $\operatorname{Ar}(50 \mathrm{~mL} / \mathrm{min})$ to remove excess $\mathrm{H}_{2}$. The catalyst was again subjected to flowing $1 \% \mathrm{CO} / \mathrm{Ar}(50 \mathrm{~mL} / \mathrm{min})$ at $25^{\circ} \mathrm{C}$ for $1 \mathrm{~h}$, followed by Ar purging to remove gas phase $\mathrm{CO}$ and weakly absorbed $\mathrm{CO}$ before spectra were collected. XPS measurements were performed on a Thermo Scientific (Waltham, MA, USA) K-Alpha system utilizing $\mathrm{Al} \mathrm{K}-\alpha$ radiation and a spot size of $100 \mu \mathrm{m}$. A minimum of 15 scans were collected for the full range spectra as well as for individual element scans, each spectrum produced being the average of two sample points. A linear background correction was used for sample integration and an elemental effectiveness factor of 1.1 was applied to copper to compensate for signal intensity variation. TEM observations were conducted on the fresh and spent (after $2^{\text {nd }} 100 \mathrm{~h}$ on stream) $\mathrm{Ni}-\mathrm{Cu}$ catalyst. The catalyst powders were loaded on lacey carbon 400 mesh gold (C/Au) grids via a sonication-assisted method. This required a sample of the catalyst powder to be sonicated in $1 \mathrm{~mL}$ of ethanol for $20 \mathrm{~min}$ before placing one drop of the resulting suspension solution onto a blank C/ $\mathrm{Au}$ grid that was subsequently allowed to dry in air. Samples thus prepared were then introduced into a Thermo Scientific (Waltham, MA, USA) Talos F200X analytical electron microscope, operated at $200 \mathrm{keV}$ and equipped with four silicon drift detector (SDD)-based EDS systems for quantitative chemical composition analysis and elemental distribution mapping.

\subsection{Feed Preparation}

A waste FFA feedstock was obtained from the steam stripping of triglyceride-based feeds used for biodiesel synthesis. BG from waste water grease traps was supplied by Pincelli and Associates (Chattanooga, TN, USA). The BG was mixed vigorously with $25 \mathrm{wt} \%$ chloroform (HPLC grade, supplied by J.T. Baker, Radnor, PA, USA) for $2 \mathrm{~h}$ at $30^{\circ} \mathrm{C}$. The resulting solution was filtered with occasional heating to counter the solidification of fats. The water layer from the resulting filtrate was then decanted and the remaining organic mixture was dried using $\mathrm{Na}_{2} \mathrm{SO}_{4}$. The chloroform was removed by rotatory evaporation and the remaining lipids were diluted to the desired concentration with n-dodecane $(99+\%$, Alfa Aesar, Haverhill, MA, USA).

\subsection{Continuous Fixed-Bed Deoxygenation Experiments}

Experiments were operated in continuous mode using a fixed bed stainless steel tubular reactor $(1 / 2$ in o.d., Parr, Moline, IL, USA) with a stainless steel porous frit to hold the catalyst bed in place. A mixture of equal parts catalyst and $\mathrm{SiC}$ diluent (by weight, $1 \mathrm{~g}$ total) was used for all experiments. The catalyst was reduced in situ at $400{ }^{\circ} \mathrm{C}$ for $3 \mathrm{~h}$ under flowing $\mathrm{H}_{2}(60 \mathrm{~mL} / \mathrm{min})$. Temperature was monitored using two K-type thermocouples, one introduced from above and made to contact the catalyst bed and one introduced from below and made to contact the aforementioned porous frit under the catalyst bed. For experiments in which the reaction atmosphere was not pure $\mathrm{H}_{2}$, the reactor was purged after the reduction with Ar and pressurized with the reaction gas to 40 bar. The pressure was monitored both upstream and downstream of the catalyst bed by Omega (Norwalk, CT, USA) digital pressure gauges. After the system was pressurized, the catalyst bed was heated to the desired reaction temperature $\left(275-375^{\circ} \mathrm{C}\right)$. The liquid feed solution was introduced to the reactor using a Harvard 
Apparatus (Holliston, MA, USA) syringe pump equipped with an $8 \mathrm{~mL}$ syringe, either at $0.043 \mathrm{~mL} / \mathrm{min}$ for the FFA feed ( $25 \mathrm{wt} \%$ in C12) or at $0.021 \mathrm{~mL} / \mathrm{min}$ for BG (50 $\mathrm{wt} \%$ in C12) to achieve a weight hour space velocity (WHSV) of $1 \mathrm{~h}^{-1}$. The flow of the reaction gas was held at $60 \mathrm{~mL} / \mathrm{min}$ for the duration of the experiment. Liquid products were sampled from a liquid-gas separator (kept at $0{ }^{\circ} \mathrm{C}$ ) placed downstream from the catalyst bed. Incondensable gases were directed to a dry test meter before being collected in Tedlar ${ }^{\circledR}$ gas sample bags. Gas sample bags were changed every time a liquid sample was taken to ensure that the gas samples analyzed and the liquid samples collected could be correlated. Representative experiments were performed in duplicate to ensure reproducibility. The average standard deviation of diesel-like hydrocarbons and heavy products formed was $2.77 \%$ and $1.47 \%$ in duplicate FFA and BG upgrading experiments, respectively.

\subsection{Liquid and Gaseous Product Analysis}

The liquid products were analyzed using a combined simulated-distillation-GC and GC-MS method specifically devised to identify and quantify the products obtained in the upgrading of FOG to hydrocarbons. Detailed information about the development and application of this method is available elsewhere [39]. Briefly, the analyses were performed using an Agilent (Santa Clara, CA, USA) 7890B GC system equipped with an Agilent (Santa Clara, CA, USA) 5977A extractor MSD and flame ionization detector (FID). The multimode inlet, which contained a helix liner, was run in a split mode (15:1; split flow, $48 \mathrm{~mL} / \mathrm{min}$ ) with an initial temperature of $100{ }^{\circ} \mathrm{C}$. Helium was used as the carrier gas and a $1 \mu \mathrm{L}$ injection was employed. Upon injection, the inlet temperature was immediately increased to $380^{\circ} \mathrm{C}$ at a rate of $8{ }^{\circ} \mathrm{C} / \mathrm{min}$, and the temperature was maintained for the course of the analysis. The oven temperature was increased upon injection from $40{ }^{\circ} \mathrm{C}$ to $325{ }^{\circ} \mathrm{C}$ at a rate of $4{ }^{\circ} \mathrm{C} / \mathrm{min}$, followed by a ramp of $10{ }^{\circ} \mathrm{C} / \mathrm{min}$ to $400{ }^{\circ} \mathrm{C}$, which was maintained for $12.5 \mathrm{~min}$. The total analysis run time was $91.25 \mathrm{~min}$. An Agilent (Santa Clara, CA, USA) J and W VF-5ht column $(30 \mathrm{~m} \times 250 \mu \mathrm{m} \times 0.1 \mu \mathrm{m})$ rated to $450{ }^{\circ} \mathrm{C}$ was used. Column eluents were directed to a Siltek MXT ${ }^{\mathrm{TM}}$ connector that split the flow into two streams, one leading to the MSD (J and W Ultimetal Plus Tubing, $11 \mathrm{~m} \times 0.25 \mathrm{~mm}$ i.d.) and one leading to the FID ( $\mathrm{J}$ and W Ultimetal Plus Tubing, $5 \mathrm{~m} \times 0.25 \mathrm{~mm}$ i.d.). The MS zone temperatures (MS source at $230{ }^{\circ} \mathrm{C}$ and quadrupole at $150^{\circ} \mathrm{C}$ ) were held constant for the duration of the analysis. A 1.75 min solvent delay was implemented and the MSD scanned from 10 to $700 \mathrm{Da}$. The FID was set to $390^{\circ} \mathrm{C}$ with the following gas flow rates: $\mathrm{H}_{2}$ at $40 \mathrm{~mL} / \mathrm{min}$; air at $400 \mathrm{~mL} / \mathrm{min}$; He makeup at $25 \mathrm{~mL} / \mathrm{min}$. Quantification was performed using cyclohexanone as an internal standard. Agilent (Santa Clara, CA, USA) MassHunter Acquisition and SimDis Expert 9-purchased from Separation Systems Inc. (Gulf Breeze, FL, USA)—software were respectively used to perform chromatographic programming and to process the GC-FID data acquired. Solvents (i.e., chloroform and dodecane) were quenched and/or subtracted prior to processing the data.

Gaseous samples were analyzed using an Agilent (Santa Clara, CA, USA) 3000 Micro-GC equipped with $5 \AA$ molecular sieve, PoraPLOT U, alumina, and OV-1 columns. The GC was calibrated for all of the gaseous products obtained, including $\mathrm{CO}_{\mathrm{x}}$, as well as straight chain $\mathrm{C} 1-\mathrm{C} 6$ alkanes and alkenes.

\section{Conclusions}

$20 \% \mathrm{Ni}-5 \% \mathrm{Cu} / \mathrm{Al}_{2} \mathrm{O}_{3}$ was found to be an effective catalyst in the deoxygenation of fatty acid waste streams to fuel-like hydrocarbons. Near quantitative conversion of a free fatty acid feed obtained by steam stripping a biodiesel feedstock ( $25 \mathrm{wt} \%$ in dodecane) was achieved at all the reaction temperatures employed, i.e., 275,325 , and $375{ }^{\circ} \mathrm{C}$. Notably, upon increasing the lipid concentration-from the $25 \mathrm{wt} \%$ used in experiments involving the feed obtained by steam stripping to the $50 \mathrm{wt} \%$ used in experiments involving BG-quantitative conversion of the BG lipids to hydrocarbons was obtained in experiments performed at 325 and $375{ }^{\circ} \mathrm{C}$. While the $20 \% \mathrm{Ni}-5 \%$ $\mathrm{Cu} / \mathrm{Al}_{2} \mathrm{O}_{3}$ catalyst yielded a larger amount of heavy chain hydrocarbons during the upgrading of $\mathrm{BG}$ under reduced $\mathrm{H}_{2}$ partial pressure, $\mathrm{CO}_{x}$ methanation (and the associated $\mathrm{H}_{2}$ consumption) was significantly reduced. Saliently, the $20 \% \mathrm{Ni}-5 \% \mathrm{Cu} / \mathrm{Al}_{2} \mathrm{O}_{3}$ catalyst gave yields of diesel-like 
hydrocarbons in excess of $80 \%$ at all reaction times during a BG upgrading experiment lasting $100 \mathrm{~h}$. Moreover, the catalyst was successfully regenerated in situ and displayed improved deoxygenation and decreased cracking and methanation activity during a second $100 \mathrm{~h}$ cycle, which is ascribed to irreversible poisoning of cracking and $\mathrm{CO}$ adsorption sites and/or to the decrease in the $\mathrm{CO}$ binding energy to $\mathrm{Ni}$ sites. Indeed, the lower concentration of $\mathrm{CO}$ on the catalyst surface decreases catalyst poisoning from $\mathrm{CO}$-resulting in the superior activity and stability observed by the regenerated catalyst-as well as the likelihood of methane and coke formation. This conclusion is supported by data pertaining to the characterization of the fresh and spent (after the second $100 \mathrm{~h}$ on stream) catalyst via TEM-EDS, CO-DRIFTS, and XPS, analytical results showing that metal particle sintering, alloying of $\mathrm{Ni}$ with $\mathrm{Cu}$, as well as both surface and bulk particle enrichment with copper all occur in the course of reaction and/or catalyst regeneration. Taken together, these results explain the superior properties of the regenerated catalyst in lipid deoxygenation relative to its fresh counterpart. Overall, these results confirm that $20 \% \mathrm{Ni}-5 \% \mathrm{Cu} / \mathrm{Al}_{2} \mathrm{O}_{3}$ is a robust and effective catalyst for the conversion of waste lipid streams to diesel-range hydrocarbons.

Supplementary Materials: The following are available online at http:/ /www.mdpi.com/2073-4344/9/2/123/s1. Figure S1: GC analysis of gas samples in the deoxygenation of BG lipids at (a) $325^{\circ} \mathrm{C}$ and (b) $375{ }^{\circ} \mathrm{C}$.

Author Contributions: Individual contributions are as follows: conceptualization: E.S.-J. and M.C.; methodology: R.L., E.S.-J. and M.C.; software: M.M.; validation: R.L., Y.L., and M.M.; formal analysis: R.L. and T.M.; investigation: R.L., T.M., Y.L., M.M., D.Q., R.P., and M.A.; resources: E.S.-J. and M.C.; data curation: R.L.; writing-original draft preparation: R.L. and R.P.; writing-review and editing: E.S.-J. and M.C.; visualization: R.L., Y.L., and M.M.; supervision: R.L., E.S.-J., and M.C.; project administration: E.S.-J. and M.C.; funding acquisition: E.S.-J. and M.C.

Funding: This work was supported in part by the National Science Foundation (NSF) under grant nos. 1437604, 1531637, and 1444779, as well as by a research support grant from the University of Kentucky Office of the Vice-President for Research.

Acknowledgments: Brad Davis of ESC Energy is thanked for providing the sample of waste FFAs used in this study. Beth Hamilton of Pincelli and Associates is thanked for providing the sample of brown grease used in this study. Maria Wright is thanked for her assistance with feed preparation.

Conflicts of Interest: The authors declare no conflict of interest. The funders had no role in the design of the study; in the collection, analyses, or interpretation of data; in the writing of the manuscript; or in the decision to publish the results.

\section{Appendix A}

Table A1. GC-MS analysis of the feed mixtures used in the catalytic upgrading experiments over $20 \% \mathrm{Ni}-5 \% \mathrm{Cu} / \mathrm{Al}_{2} \mathrm{O}_{3}$. Text in bold corresponds to compound classes comprising the individual compounds listed.

\begin{tabular}{ccc}
\hline Compound & Fatty Acid Feed & Brown Grease \\
\hline Alkenes & $\mathbf{0 . 6 3}$ & - \\
Neophytadiene & 0.30 & - \\
Squalene & 0.33 & - \\
Fatty Acids & $\mathbf{9 6 . 2 1}$ & $\mathbf{9 7 . 3 3}$ \\
Decanoic Acid (C10:0) & - & 0.07 \\
Lauric acid (C12:0) & - & 0.13 \\
Myristic Acid (C14:0) & 0.88 & 1.55 \\
Pentadecanoic acid (C15:0) & - & 0.10 \\
Palmitoleic acid (C16:1) & 1.64 & 0.72 \\
Palmitic acid (C16:0) & 21.21 & 20.42 \\
Heptadecanoic acid (C17:0) & - & 0.33 \\
Oleic acid (C18:1) & 63.52 & 64.52 \\
Stearic acid (C18:0) & 8.96 & 8.73 \\
cis-13-eicosenoic acid (C20:1) & - & 0.53 \\
Eicosanoic acid (C20:0) & - & 0.23 \\
\hline
\end{tabular}


Table A1. Cont.

\begin{tabular}{ccc}
\hline Compound & Fatty Acid Feed & Brown Grease \\
\hline Esters & $\mathbf{2 . 2 8}$ & - \\
Methyl Palmitate & 0.26 & - \\
Methyl linoleate & 0.65 & - \\
Methyl oleate & 0.76 & - \\
Stearyl oleate & 0.61 & - \\
Alcohols & $\mathbf{0 . 3 9}$ & - \\
Phytol & 0.39 & - \\
Glycerides & - & $\mathbf{2 . 6 6}$ \\
Dipalmitin & - & 0.34 \\
Diolein & - & 1.91 \\
Tripalmitin & - & 0.05 \\
Tristearin & - & 0.22 \\
Unidentified & - & 0.14 \\
Other (mixed chain) triglycerides & $\mathbf{0 . 4 9}$ & - \\
\hline
\end{tabular}

Table A2. GC-MS analysis of the liquid product mixtures in the catalytic upgrading of fatty acid feed (25 wt \% in C12) over $20 \% \mathrm{Ni}-5 \% \mathrm{Cu} / \mathrm{Al}_{2} \mathrm{O}_{3}$ at $275{ }^{\circ} \mathrm{C}$ and WHSV $=1.0 \mathrm{~h}^{-1}$, in $100 \% \mathrm{H}_{2}$. Text in bold corresponds to compound classes comprising the individual compounds listed.

\begin{tabular}{|c|c|c|c|c|c|c|c|c|}
\hline Compound & $1 \mathrm{~h}$ & $2 \mathrm{~h}$ & $3 \mathrm{~h}$ & $4 \mathrm{~h}$ & $5 \mathrm{~h}$ & $6 \mathrm{~h}$ & $7 \mathrm{~h}$ & $8 \mathrm{~h}$ \\
\hline Normal Alkanes & 84.84 & 80.26 & 78.38 & 77.46 & 74.75 & 72.93 & 69.85 & 66.36 \\
\hline Decane (C10) & 0.21 & 0.13 & 0.13 & 0.14 & 0.12 & 0.17 & 0.12 & 0.17 \\
\hline Undecane (C11) & 1.10 & 0.51 & 0.59 & 0.39 & 0.50 & 0.44 & 0.50 & 0.31 \\
\hline Tridecane (C13) & 1.44 & 1.70 & 1.69 & 1.37 & 1.25 & 1.37 & 1.52 & 1.28 \\
\hline Tetradecane (C14) & 0.19 & 0.31 & 0.33 & 0.31 & 0.25 & 0.28 & 0.24 & 0.14 \\
\hline Pentadecane (C15) & 21.57 & 20.29 & 20.68 & 20.81 & 18.92 & 18.63 & 18.90 & 17.90 \\
\hline Hexadecane (C16) & 1.01 & 0.98 & 1.02 & 0.70 & 1.00 & 0.71 & 0.77 & 0.71 \\
\hline Heptadecane (C17) & 55.99 & 53.18 & 50.41 & 50.69 & 49.55 & 47.73 & 44.01 & 41.51 \\
\hline Octadecane (C18) & 1.11 & 1.04 & 1.00 & 0.85 & 0.84 & 0.99 & 0.83 & 0.71 \\
\hline Nonadecane (C19) & 0.95 & 0.72 & 0.82 & 0.66 & 0.77 & 0.71 & 0.90 & 0.89 \\
\hline Heneicosane (C21) & 0.60 & 0.69 & 0.83 & 0.44 & 0.79 & 0.74 & 0.82 & 1.26 \\
\hline Tricosane (C23) & 0.37 & 0.43 & 0.59 & 0.73 & 0.55 & 0.85 & 0.89 & 1.11 \\
\hline Hexacosane (C26) & 0.30 & 0.28 & 0.29 & 0.37 & 0.21 & 0.31 & 0.35 & 0.37 \\
\hline Olefins & 0.61 & 0.53 & 0.83 & 0.88 & 0.83 & 0.69 & 0.82 & 0.73 \\
\hline Heptadecene (C17:1) & 0.48 & 0.34 & 0.50 & 0.66 & 0.48 & 0.33 & 0.46 & 0.36 \\
\hline Octadecene (C18:1) & 0.13 & 0.19 & 0.33 & 0.22 & 0.35 & 0.36 & 0.36 & 0.37 \\
\hline Branded Alkanes & 5.97 & 6.86 & 6.83 & 7.83 & 8.67 & 9.02 & 9.70 & 10.52 \\
\hline Phytane & 2.70 & 2.74 & 2.90 & 2.97 & 3.02 & 3.25 & 3.58 & 3.52 \\
\hline Squalane & 0.51 & 0.52 & 0.55 & 0.58 & 0.51 & 0.56 & 0.55 & 0.67 \\
\hline Coprostane & 0.56 & 0.83 & 0.62 & 0.70 & 0.79 & 0.86 & 0.86 & 0.98 \\
\hline Cholestane & 0.77 & 1.05 & 0.97 & 1.37 & 1.66 & 1.70 & 1.67 & 1.99 \\
\hline Stigmastane & 0.47 & 0.54 & 0.56 & 0.62 & 0.75 & 0.66 & 0.65 & 0.73 \\
\hline Stigmastane * & 0.96 & 1.18 & 1.23 & 1.59 & 1.94 & 1.99 & 2.39 & 2.63 \\
\hline Total Oxygenates & 8.60 & 12.37 & 13.94 & 13.84 & 15.76 & 17.36 & 19.62 & 22.38 \\
\hline Methyl Stearate & 0.50 & 1.30 & 1.77 & 2.12 & 3.42 & 4.25 & 4.78 & 6.47 \\
\hline Lauryl Stearate & 1.09 & 1.27 & 1.94 & 2.18 & 2.36 & 2.67 & 3.24 & 3.38 \\
\hline Cetyl Palmitate & 2.61 & 3.52 & 3.84 & 3.76 & 3.95 & 4.25 & 4.59 & 4.78 \\
\hline Cetyl Stearate & 3.00 & 4.03 & 4.31 & 3.72 & 3.65 & 3.75 & 4.20 & 3.98 \\
\hline Stearyl Stearate & 1.40 & 2.25 & 2.08 & 2.06 & 2.38 & 2.44 & 2.81 & 3.77 \\
\hline
\end{tabular}

* Different isomer. 
Table A3. GC-MS analysis of the liquid product mixtures in the catalytic upgrading of fatty acid feed ( $25 \mathrm{wt} \%$ in $\mathrm{C} 12$ ) over $20 \% \mathrm{Ni}-5 \% \mathrm{Cu} / \mathrm{Al}_{2} \mathrm{O}_{3}$ at $325^{\circ} \mathrm{C}$ and WHSV $=1.0 \mathrm{~h}^{-1}$, in $100 \% \mathrm{H}_{2}$. Text in bold corresponds to compound classes comprising the individual compounds listed.

\begin{tabular}{|c|c|c|c|c|c|c|c|c|}
\hline Compound & $1 \mathrm{~h}$ & $2 \mathrm{~h}$ & $3 \mathrm{~h}$ & $4 \mathrm{~h}$ & $5 \mathrm{~h}$ & $6 \mathrm{~h}$ & $7 \mathrm{~h}$ & $8 \mathrm{~h}$ \\
\hline Normal Alkanes & 97.84 & 91.08 & 95.69 & 96.33 & 95.43 & 95.90 & 96.07 & 95.23 \\
\hline Decane (C10) & 1.54 & 2.83 & 1.51 & 1.55 & 1.45 & 1.43 & 1.50 & 1.43 \\
\hline Undecane (C11) & 2.13 & 2.48 & 1.50 & 1.44 & 1.59 & 1.60 & 2.10 & 1.25 \\
\hline Tridecane (C13) & 1.74 & 3.13 & 1.66 & 1.68 & 1.65 & 1.64 & 1.40 & 1.66 \\
\hline Tetradecane (C14) & 0.90 & 2.32 & 0.89 & 0.75 & 0.76 & 0.82 & 0.80 & 0.90 \\
\hline Pentadecane (C15) & 25.48 & 16.89 & 25.69 & 25.45 & 24.37 & 24.22 & 23.36 & 23.24 \\
\hline Hexadecane (C16) & 3.16 & 7.98 & 3.53 & 3.47 & 3.73 & 3.79 & 3.83 & 4.10 \\
\hline Heptadecane (C17) & 51.99 & 37.30 & 52.00 & 52.31 & 51.50 & 51.90 & 52.12 & 51.58 \\
\hline Octadecane (C18) & 5.77 & 10.83 & 4.32 & 4.83 & 5.74 & 5.55 & 5.76 & 6.10 \\
\hline Nonadecane (C19) & 1.19 & 1.43 & 0.82 & 0.81 & 0.83 & 1.07 & 0.86 & 1.01 \\
\hline Eicosane (C20) & 0.26 & 0.88 & 0.23 & 0.32 & 0.25 & 0.21 & 0.34 & 0.26 \\
\hline Heneicosane (C21) & 0.55 & 0.66 & 0.35 & 0.45 & 0.43 & 0.36 & 0.50 & 0.26 \\
\hline Docosane (C22) & 0.35 & 0.75 & 0.21 & 0.29 & 0.20 & 0.20 & 0.29 & 0.20 \\
\hline Tricosane (C23) & 0.39 & 0.78 & 0.46 & 0.31 & 0.35 & 0.42 & 0.38 & 0.34 \\
\hline Tetracosane (C24) & 0.33 & 0.48 & 0.37 & 0.36 & 0.28 & 0.39 & 0.41 & 0.32 \\
\hline Pentacosane (C25) & 0.33 & 0.42 & 0.34 & 0.42 & 0.32 & 0.33 & 0.41 & 0.37 \\
\hline Hexacosane (C26) & 0.42 & 0.35 & 0.53 & 0.42 & 0.51 & 0.50 & 0.60 & 0.47 \\
\hline Heptacosane (C27) & 0.26 & 0.29 & 0.27 & 0.33 & 0.31 & 0.17 & 0.22 & 0.32 \\
\hline Octacosane (C28) & 0.14 & 0.21 & 0.11 & 0.11 & 0.16 & 0.11 & 0.13 & 0.12 \\
\hline Nonacosane (C29) & 0.16 & 0.35 & 0.17 & 0.17 & 0.15 & 0.22 & 0.22 & 0.22 \\
\hline Triacontane (C30) & 0.14 & 0.12 & 0.09 & 0.18 & 0.05 & 0.09 & 0.07 & 0.09 \\
\hline Hentriacontane (C31) & 0.28 & 0.22 & 0.23 & 0.26 & 0.28 & 0.32 & 0.28 & 0.33 \\
\hline Tritriacontane (C33) & 0.26 & 0.20 & 0.30 & 0.31 & 0.38 & 0.39 & 0.37 & 0.48 \\
\hline Pentatriacontane (C35) & 0.07 & 0.18 & 0.11 & 0.11 & 0.14 & 0.17 & 0.12 & 0.18 \\
\hline Olefins & 1.96 & 6.41 & 1.71 & 1.28 & 1.81 & 1.60 & 1.36 & 1.60 \\
\hline Heptadecene (C17:1) & 1.96 & 3.90 & 1.59 & 1.06 & 1.64 & 1.39 & 1.10 & 1.19 \\
\hline Octadecene (18:1) & - & 2.51 & 0.12 & 0.22 & 0.17 & 0.21 & 0.26 & 0.41 \\
\hline Branched Alkanes & - & 2.48 & 2.62 & 2.39 & 2.76 & 2.51 & 2.57 & 2.98 \\
\hline Phytane & - & 2.48 & 2.62 & 2.39 & 2.76 & 2.51 & 2.57 & 2.98 \\
\hline Total Oxygenates & 0.19 & - & - & - & - & - & - & 0.20 \\
\hline Cetyl Stearate & 0.13 & - & - & - & - & - & - & 0.14 \\
\hline Stearyl Stearate & 0.06 & - & - & - & - & - & - & 0.06 \\
\hline
\end{tabular}

Table A4. GC-MS analysis of the liquid product mixtures in the catalytic upgrading of fatty acid feed ( $25 \mathrm{wt} \%$ in $\mathrm{C} 12$ ) over $20 \% \mathrm{Ni}-5 \% \mathrm{Cu} / \mathrm{Al}_{2} \mathrm{O}_{3}$ at $375{ }^{\circ} \mathrm{C}$ and WHSV $=1.0 \mathrm{~h}^{-1}$, in $100 \% \mathrm{H}_{2}$. Text in bold corresponds to compound classes comprising the individual compounds listed.

\begin{tabular}{ccccccccc}
\hline Compound & $\mathbf{1} \mathbf{h}$ & $\mathbf{2} \mathbf{h}$ & $\mathbf{3} \mathbf{h}$ & $\mathbf{4} \mathbf{h}$ & $\mathbf{5} \mathbf{h}$ & $\mathbf{6} \mathbf{h}$ & $\mathbf{7} \mathbf{h}$ & $\mathbf{8} \mathbf{h}$ \\
\hline Normal Alkanes & $\mathbf{1 0 0 . 0 0}$ & $\mathbf{1 0 0 . 0 0}$ & $\mathbf{1 0 0 . 0 0}$ & $\mathbf{1 0 0 . 0 0}$ & $\mathbf{1 0 0 . 0 0}$ & $\mathbf{1 0 0 . 0 0}$ & $\mathbf{1 0 0 . 0 0}$ & $\mathbf{1 0 0 . 0 0}$ \\
Octane (C8) & 1.74 & 1.21 & 1.03 & 0.98 & 0.95 & 0.84 & 0.75 & 0.68 \\
Decane (C10) & 1.38 & 0.75 & 0.62 & 0.60 & 0.47 & 0.53 & 0.52 & 0.52 \\
Tridecane (C13) & 0.99 & 0.87 & 0.77 & 0.75 & 0.71 & 0.78 & 0.74 & 0.75 \\
Tetradecane (C14) & 1.30 & 1.27 & 1.24 & 1.26 & 0.83 & 1.27 & 1.22 & 1.27 \\
Pentadecane (C15) & 14.05 & 12.46 & 11.85 & 11.89 & 11.93 & 11.86 & 11.52 & 11.77 \\
Hexadecane (C16) & 14.79 & 14.98 & 14.81 & 14.84 & 14.71 & 14.78 & 14.63 & 14.67 \\
Heptadecane (C17) & 35.04 & 33.41 & 32.46 & 31.88 & 31.42 & 31.04 & 31.45 & 31.69 \\
Octadecane (C18) & 28.95 & 32.69 & 34.53 & 35.12 & 36.49 & 36.15 & 36.20 & 36.09 \\
Nonadecane (C19) & 0.50 & 0.63 & 0.65 & 0.67 & 0.60 & 0.71 & 0.87 & 0.74 \\
Eicosane (C20) & 0.29 & 0.38 & 0.41 & 0.44 & 0.44 & 0.45 & 0.51 & 0.37 \\
Heneicosane (C21) & 0.16 & 0.23 & 0.25 & 0.26 & 0.22 & 0.30 & 0.29 & 0.27 \\
Docosane (C22) & 0.06 & 0.22 & 0.20 & 0.17 & 0.19 & 0.22 & 0.25 & 0.19 \\
Tricosane (C23) & 0.12 & 0.19 & 0.25 & 0.30 & 0.27 & 0.29 & 0.31 & 0.30 \\
Hentriacontane (C31) & 0.11 & 0.15 & 0.19 & 0.26 & 0.24 & 0.29 & 0.28 & 0.27 \\
Dotriacontane (C32) & 0.27 & 0.31 & 0.36 & 0.36 & 0.33 & 0.32 & 0.29 & 0.28 \\
Tritriacontane (C33) & 0.25 & 0.25 & 0.39 & 0.22 & 0.20 & 0.16 & 0.16 & 0.14 \\
\hline
\end{tabular}


Table A5. GC-MS analysis of the liquid product mixtures in the catalytic upgrading of brown grease (50 wt \% in C12) over $20 \% \mathrm{Ni}-5 \% \mathrm{Cu} / \mathrm{Al}_{2} \mathrm{O}_{3}$ at $325^{\circ} \mathrm{C}$ and WHSV $=1.0 \mathrm{~h}^{-1}$, in $100 \% \mathrm{H}_{2}$. Text in bold corresponds to compound classes comprising the individual compounds listed.

\begin{tabular}{|c|c|c|c|c|c|c|c|c|}
\hline Compound & $1 \mathrm{~h}$ & $2 \mathrm{~h}$ & $3 \mathrm{~h}$ & $4 \mathrm{~h}$ & $5 \mathrm{~h}$ & $6 \mathrm{~h}$ & $7 \mathrm{~h}$ & $8 \mathrm{~h}$ \\
\hline Normal Alkanes & 92.05 & 90.64 & 90.53 & 93.00 & 92.64 & 92.97 & 94.06 & 97.08 \\
\hline Decane (C10) & 1.79 & 1.50 & 1.64 & 1.67 & 1.67 & 1.25 & 1.22 & 1.32 \\
\hline Undecane (C11) & 1.45 & 1.32 & 1.39 & 1.43 & 1.31 & 1.24 & 1.25 & 1.72 \\
\hline Tridecane (C13) & 2.21 & 2.24 & 2.27 & 2.30 & 1.81 & 2.18 & 2.06 & 2.70 \\
\hline Tetradecane (C14) & 1.99 & 1.78 & 1.69 & 1.61 & 1.46 & 1.40 & 1.45 & 1.65 \\
\hline Pentadecane (C15) & 13.62 & 14.32 & 15.03 & 16.14 & 16.30 & 15.38 & 13.40 & 15.72 \\
\hline Hexadecane (C16) & 10.24 & 8.82 & 8.12 & 7.32 & 7.88 & 4.92 & 7.29 & 8.34 \\
\hline Heptadecane (C17) & 33.72 & 35.68 & 36.67 & 37.31 & 37.14 & 41.23 & 45.05 & 37.78 \\
\hline Octadecane (C18) & 18.56 & 15.71 & 14.03 & 13.77 & 13.60 & 12.73 & 11.73 & 14.89 \\
\hline Nonadecane (C19) & 1.14 & 1.24 & 1.27 & 1.26 & 1.21 & 1.30 & 1.08 & 0.96 \\
\hline Eicosane (C20) & 0.70 & 0.70 & 0.68 & 0.79 & 0.81 & 0.70 & 0.70 & 0.97 \\
\hline Heneicosane (C21) & 0.61 & 0.78 & 0.65 & 0.57 & 0.50 & 1.11 & 1.91 & 3.70 \\
\hline Docosane (C22) & 0.51 & 0.46 & 0.48 & 0.46 & 0.52 & 1.12 & 0.59 & 0.67 \\
\hline Tricosane (C23) & 0.64 & 0.61 & 0.62 & 0.83 & 0.69 & 1.00 & 0.77 & 0.62 \\
\hline Tetracosane (C24) & 0.59 & 0.57 & 0.52 & 0.82 & 0.53 & 0.70 & 0.52 & 0.56 \\
\hline Pentacosane (C25) & 0.55 & 0.54 & 0.56 & 0.60 & 0.56 & 0.93 & 0.59 & 0.67 \\
\hline Hexacosane (C26) & 0.55 & 0.58 & 0.59 & 0.75 & 0.68 & 0.97 & 0.51 & 0.60 \\
\hline Heptacosane (C27) & 0.43 & 0.51 & 0.48 & 0.54 & 0.54 & 0.64 & 0.54 & 0.76 \\
\hline Octacosane (C28) & 0.32 & 0.36 & 0.35 & 0.41 & 0.39 & 0.61 & 0.38 & 0.62 \\
\hline Nonacosane (C29) & 0.35 & 0.37 & 0.40 & 0.51 & 0.49 & 0.66 & 0.59 & 0.46 \\
\hline Triacontane (C30) & 0.17 & 0.21 & 0.23 & 0.31 & 0.40 & 0.30 & 0.23 & 0.24 \\
\hline Hentriacontane (C31) & 0.58 & 0.67 & 0.78 & 0.92 & 0.97 & 0.90 & 0.50 & 0.54 \\
\hline Tritriacontane (C33) & 0.86 & 1.02 & 1.27 & 1.59 & 1.84 & 1.11 & 0.92 & 0.75 \\
\hline Pentatriacontane (C35) & 0.47 & 0.65 & 0.81 & 1.09 & 1.34 & 0.59 & 0.78 & 0.84 \\
\hline Branched Alkanes & 4.13 & 4.17 & 3.89 & 3.57 & 3.12 & 2.00 & 1.20 & 1.02 \\
\hline Phytane & 4.13 & 4.17 & 3.89 & 3.57 & 3.12 & 2.00 & 1.20 & 1.02 \\
\hline Olefins & 3.81 & 5.18 & 5.60 & 3.41 & 4.24 & 5.01 & 4.76 & 1.91 \\
\hline Heptadecene & 1.37 & 2.98 & 3.25 & 1.60 & 2.65 & 3.54 & 3.34 & 0.98 \\
\hline Octadecene & 2.44 & 2.20 & 2.35 & 1.81 & 1.59 & 1.47 & 1.42 & 0.93 \\
\hline
\end{tabular}

Table A6. GC-MS analysis of the liquid product mixtures in the catalytic upgrading of brown grease (50 wt $\%$ in C12) over $20 \% \mathrm{Ni}-5 \% \mathrm{Cu} / \mathrm{Al}_{2} \mathrm{O}_{3}$ at $375{ }^{\circ} \mathrm{C}$ and WHSV $=1.0 \mathrm{~h}^{-1}$, in $100 \% \mathrm{H}_{2}$. Text in bold corresponds to compound classes comprising the individual compounds listed.

\begin{tabular}{ccccccccc}
\hline Compound & $\mathbf{1 ~ h}$ & $\mathbf{2} \mathbf{h}$ & $\mathbf{3} \mathbf{h}$ & $\mathbf{4} \mathbf{h}$ & $\mathbf{5} \mathbf{h}$ & $\mathbf{6} \mathbf{h}$ & $\mathbf{7} \mathbf{h}$ & $\mathbf{8} \mathbf{h}$ \\
\hline Normal Alkanes & $\mathbf{1 0 0 . 0 0}$ & $\mathbf{1 0 0 . 0 0}$ & $\mathbf{1 0 0 . 0 0}$ & $\mathbf{1 0 0 . 0 0}$ & $\mathbf{1 0 0 . 0 0}$ & $\mathbf{1 0 0 . 0 0}$ & $\mathbf{1 0 0 . 0 0}$ & $\mathbf{1 0 0 . 0 0}$ \\
Decane (C10) & 4.03 & 3.68 & 3.37 & 3.34 & 3.59 & 3.52 & 3.63 & 3.29 \\
Undecane (C11) & 3.86 & 3.29 & 2.90 & 2.76 & 2.78 & 2.69 & 2.50 & 2.47 \\
Tridecane (C13) & 3.22 & 3.01 & 3.19 & 3.06 & 3.06 & 3.17 & 2.63 & 2.77 \\
Tetradecane (C14) & 2.26 & 2.06 & 2.06 & 1.95 & 1.90 & 1.89 & 1.95 & 1.93 \\
Pentadecane (C15) & 20.13 & 19.79 & 20.29 & 20.43 & 20.55 & 20.46 & 19.67 & 20.19 \\
Hexadecane (C16) & 7.67 & 7.32 & 6.82 & 6.82 & 6.83 & 6.77 & 6.84 & 7.20 \\
Heptadecane (C17) & 36.80 & 39.00 & 39.33 & 38.62 & 38.34 & 39.16 & 38.74 & 39.18 \\
Octadecane (C18) & 8.74 & 9.04 & 8.45 & 7.71 & 7.42 & 7.58 & 7.84 & 7.96 \\
Nonadecane (C19) & 1.13 & 1.21 & 1.27 & 1.26 & 1.24 & 1.25 & 1.29 & 1.25 \\
Eicosane (C20) & 0.39 & 0.55 & 0.37 & 0.41 & 0.39 & 0.43 & 0.47 & 0.61 \\
Heneicosane (C21) & 0.44 & 0.50 & 0.56 & 0.52 & 0.59 & 0.60 & 0.69 & 0.64 \\
Docosane (C22) & 0.30 & 0.30 & 0.29 & 0.25 & 0.31 & 0.34 & 0.33 & 0.38 \\
Tricosane (C23) & 0.27 & 0.31 & 0.36 & 0.41 & 0.41 & 0.53 & 0.35 & 0.52 \\
Tetracosane (C24) & 0.19 & 0.20 & 0.33 & 0.32 & 0.31 & 0.38 & 0.36 & 0.28 \\
Pentacosane (C25) & 0.14 & 0.18 & 0.24 & 0.29 & 0.31 & 0.25 & 0.42 & 0.31 \\
Hexacosane (C26) & 0.11 & 0.13 & 0.21 & 0.22 & 0.26 & 0.23 & 0.26 & 0.27 \\
Heptacosane (C27) & 0.15 & 0.14 & 0.23 & 0.23 & 0.30 & 0.31 & 0.35 & 0.35 \\
Octacosane (C28) & 0.09 & 0.10 & 0.19 & 0.18 & 0.19 & 0.19 & 0.24 & 0.23 \\
Nonacosane (C29) & 0.07 & 0.10 & 0.18 & 0.20 & 0.23 & 0.24 & 0.26 & 0.27 \\
Triacontane (C30) & 0.03 & 0.07 & 0.10 & 0.12 & 0.14 & 0.14 & 0.18 & 0.17 \\
Hentriacontane (C31) & 0.08 & 0.15 & 0.31 & 0.29 & 0.34 & 0.36 & 0.45 & 0.48 \\
Dotriacontane (C32) & 0.03 & 0.06 & 0.06 & 0.11 & 0.11 & 0.13 & 0.19 & 0.12 \\
Tritriacontane (C33) & 0.08 & 0.28 & 0.47 & 0.54 & 0.60 & 0.63 & 0.83 & 0.85 \\
Pentatriacontane (C35) & 0.07 & 0.27 & 0.38 & 0.42 & 0.36 & 0.40 & 0.57 & 0.64 \\
Unidentified HC & 9.74 & 8.27 & 8.05 & 9.51 & 9.43 & 8.35 & 8.97 & 7.62 \\
\hline
\end{tabular}


Table A7. GC-MS analysis of the liquid product mixtures in the catalytic upgrading of brown grease (50 wt \% in C12) over $20 \% \mathrm{Ni}-5 \% \mathrm{Cu} / \mathrm{Al}_{2} \mathrm{O}_{3}$ at $375{ }^{\circ} \mathrm{C}$ and WHSV $=1.0 \mathrm{~h}^{-1}$, in $20 \% \mathrm{H}_{2} / \mathrm{Ar}$. Text in bold corresponds to compound classes comprising the individual compounds listed.

\begin{tabular}{ccccccccc}
\hline Compound & $\mathbf{1} \mathbf{h}$ & $\mathbf{2} \mathbf{h}$ & $\mathbf{3} \mathbf{h}$ & $\mathbf{4} \mathbf{h}$ & $\mathbf{5} \mathbf{h}$ & $\mathbf{6} \mathbf{h}$ & $\mathbf{7} \mathbf{h}$ & $\mathbf{8} \mathbf{~}$ \\
\hline Normal Alkanes & $\mathbf{9 7 . 4 3}$ & $\mathbf{9 7 . 6 8}$ & $\mathbf{9 8 . 1 1}$ & $\mathbf{9 8 . 2 4}$ & $\mathbf{9 8 . 5 6}$ & $\mathbf{9 8 . 7 4}$ & $\mathbf{9 8 . 8 6}$ & $\mathbf{9 8 . 7 8}$ \\
Decane (C10) & 6.91 & 5.18 & 4.09 & 3.74 & 2.98 & 2.03 & 2.78 & 1.81 \\
Undecane (C11) & 11.15 & 8.52 & 6.45 & 5.41 & 3.93 & 2.81 & 2.88 & 2.19 \\
Tridecane (C13) & 2.94 & 3.00 & 1.57 & 2.77 & 2.70 & 2.44 & 2.75 & 2.27 \\
Tetradecane (C14) & 3.34 & 3.63 & 3.21 & 3.29 & 3.09 & 3.08 & 2.72 & 2.72 \\
Pentadecane (C15) & 14.34 & 15.13 & 16.22 & 17.57 & 16.37 & 16.72 & 16.06 & 18.35 \\
Hexadecane (C16) & 8.68 & 9.03 & 8.81 & 0.62 & 8.68 & 9.15 & 7.65 & 0.94 \\
Heptadecane (C17) & 31.75 & 33.03 & 37.74 & 41.49 & 38.16 & 39.42 & 38.63 & 45.40 \\
Octadecane (C18) & 7.73 & 8.72 & 9.02 & 10.32 & 9.92 & 10.34 & 10.57 & 13.18 \\
Nonadecane (C19) & 1.31 & 1.59 & 1.72 & 1.94 & 1.83 & 1.82 & 1.75 & 1.85 \\
Eicosane (C20) & 0.77 & 0.88 & 0.72 & 0.83 & 0.75 & 0.81 & 0.77 & 0.68 \\
Heneicosane (C21) & 0.55 & 0.67 & 0.71 & 0.87 & 0.80 & 0.68 & 0.82 & 0.76 \\
Docosane (C22) & 1.77 & 1.45 & 0.60 & 0.78 & 0.66 & 0.87 & 0.68 & 0.55 \\
Tricosane (C23) & 0.79 & 0.81 & 0.93 & 1.02 & 0.94 & 0.95 & 1.31 & 0.85 \\
Tetracosane (C24) & 0.89 & 0.88 & 1.00 & 1.10 & 1.04 & 1.12 & 1.55 & 0.93 \\
Pentacosane (C25) & 0.99 & 0.99 & 1.13 & 1.33 & 1.23 & 1.26 & 1.82 & 1.28 \\
Hexacosane (C26) & 1.04 & 1.07 & 1.12 & 1.51 & 1.63 & 1.50 & 1.99 & 1.35 \\
Heptacosane (C27) & 0.79 & 0.89 & 0.92 & 1.05 & 1.13 & 1.26 & 1.64 & 1.05 \\
Octacosane (C28) & 0.51 & 0.60 & 0.64 & 0.79 & 0.82 & 0.75 & 0.86 & 0.64 \\
Nonacosane (C29) & 0.48 & 0.59 & 0.64 & 0.83 & 0.91 & 0.77 & 0.82 & 0.75 \\
Triacontane (C30) & 0.30 & 0.40 & 0.36 & 0.38 & 0.40 & 0.32 & 0.30 & 0.59 \\
Hentriacontane (C31) & 0.40 & 0.62 & 0.51 & 0.60 & 0.59 & 0.64 & 0.51 & 0.64 \\
Total Oxygenates & $\mathbf{2 . 6 0}$ & $\mathbf{2 . 3 3}$ & $\mathbf{1 . 8 7}$ & $\mathbf{1 . 7 6}$ & $\mathbf{1 . 4 3}$ & $\mathbf{1 . 2 8}$ & $\mathbf{1 . 1 3}$ & $\mathbf{1 . 2 1}$ \\
Cetyl Stearate & 1.05 & 0.97 & 0.81 & 0.76 & 0.65 & 0.57 & 0.51 & 0.57 \\
Stearyl Stearate & 1.55 & 1.36 & 1.06 & 1.00 & 0.78 & 0.71 & 0.62 & 0.64 \\
\hline & & & & & & & &
\end{tabular}

Table A8. GC-MS analysis of the liquid products from the catalytic upgrading of brown grease (50 wt $\%$ in $\mathrm{C} 12$ ) over $20 \% \mathrm{Ni}-5 \% \mathrm{Cu} / \mathrm{Al}_{2} \mathrm{O}_{3}$ at $375{ }^{\circ} \mathrm{C}$ and WHSV $=0.8 \mathrm{~h}^{-1}$, in $100 \% \mathrm{H}_{2}$ for the first $100 \mathrm{~h}$. Text in bold corresponds to compound classes comprising the individual compounds listed. Text in italic corresponds to compound classes constituting the oxygenates detected.

\begin{tabular}{cccccc}
\hline Compound & $\mathbf{1 ~ h}$ & $\mathbf{2 4} \mathbf{h}$ & $\mathbf{4 8} \mathbf{h}$ & $\mathbf{7 2} \mathbf{~ h}$ & $\mathbf{9 6} \mathbf{~ h}$ \\
\hline Normal Alkanes & $\mathbf{9 9 . 3 0}$ & $\mathbf{9 7 . 0 7}$ & $\mathbf{9 1 . 4 1}$ & $\mathbf{8 1 . 9 8}$ & $\mathbf{7 5 . 5 6}$ \\
Decane (C10) & 4.56 & 2.15 & 3.13 & 2.89 & 3.01 \\
Undecane (C11) & 6.65 & 1.89 & 1.58 & 1.01 & 1.56 \\
Tridecane (C13) & 2.60 & 1.96 & 1.94 & 1.55 & 1.49 \\
Tetradecane (C14) & 2.73 & 1.59 & 1.54 & 1.20 & 1.11 \\
Pentadecane (C15) & 17.51 & 18.42 & 15.37 & 17.56 & 12.80 \\
Hexadecane (C16) & 9.23 & 5.54 & 4.03 & 4.26 & - \\
Heptadecane (C17) & 43.13 & 44.60 & 49.62 & 42.24 & 43.41 \\
Octadecane (C18) & 10.15 & 11.35 & 6.97 & 7.18 & 7.92 \\
Nonadecane (C19) & 0.74 & 1.16 & 0.81 & 0.89 & 0.90 \\
Eicosane (C20) & 0.25 & 1.55 & 1.62 & - & - \\
Heneicosane (C21) & 0.26 & 0.47 & 0.25 & 0.29 & 0.30 \\
Docosane (C22) & 0.13 & 1.64 & 1.23 & - & - \\
Tricosane (C23) & 0.23 & 0.59 & 0.53 & 0.49 & 0.50 \\
Tetracosane (C24) & 0.18 & 0.69 & 0.44 & 0.44 & 0.44 \\
Pentacosane (C25) & 0.22 & 0.64 & 0.57 & 0.44 & 0.49 \\
Hexacosane (C26) & 0.26 & 0.79 & 0.78 & 0.66 & 0.66 \\
Heptacosane (C27) & 0.10 & 0.48 & 0.36 & 0.32 & 0.34 \\
Octacosane (C28) & 0.08 & 0.29 & - & - & - \\
Nonacosane (C29) & 0.07 & 0.31 & - & - & - \\
Triacontane (C30) & 0.06 & 0.09 & - & - & - \\
Hentriacontane (C31) & 0.08 & 0.28 & 0.25 & 0.20 & 0.20 \\
Tritriacontane (C33) & 0.09 & 0.39 & 0.23 & 0.22 & 0.26 \\
Pentatriacontane (C35) & - & 0.20 & 0.16 & 0.14 & 0.17 \\
\hline & & & & &
\end{tabular}


Table A8. Cont.

\begin{tabular}{cccccc}
\hline Compound & $\mathbf{1 ~ h}$ & $\mathbf{2 4} \mathbf{~ h}$ & $\mathbf{4 8} \mathbf{h}$ & $\mathbf{7 2} \mathbf{~ h}$ & $\mathbf{9 6} \mathbf{~ h}$ \\
\hline Branched Alkanes & - & - & $\mathbf{0 . 9 0}$ & $\mathbf{0 . 8 5}$ & $\mathbf{0 . 9 4}$ \\
Cholestane & - & - & 0.31 & 0.30 & 0.33 \\
Coprostane & - & - & 0.33 & 0.29 & 0.33 \\
Stigmastane & - & - & 0.25 & 0.27 & 0.29 \\
Olefins & $\mathbf{0 . 7 0}$ & $\mathbf{2 . 9 3}$ & $\mathbf{7 . 7 0}$ & $\mathbf{9 . 3 0}$ & $\mathbf{1 3 . 6 1}$ \\
2-Tetradecene (C14:1) & - & - & 0.27 & 0.34 & 0.38 \\
3-Hexadecene (C16:1) & - & - & - & 0.85 & 3.95 \\
8-Heptadecene (C17:1) & 0.70 & 2.93 & 5.44 & 4.80 & 5.22 \\
1-Octadecene (C18:1) & - & - & - & 0.74 & 1.08 \\
1-Tetracosene (C24:1) & - & - & 0.13 & 0.39 & 0.47 \\
1-Pentacosene (C25:1) & - & - & 0.34 & 0.32 & 0.46 \\
1-Hexacosene (C26:1) & - & - & 0.37 & 0.47 & 0.53 \\
1-Heptacosene (C27:1) & - & - & 0.39 & 0.58 & 0.68 \\
1-Octacosene (C28:1) & - & - & 0.28 & 0.33 & 0.39 \\
1-Nonacosene (C29:1) & - & - & 0.48 & 0.47 & 0.46 \\
Total Oxygenates & - & - & - & $\mathbf{7 . 8 6}$ & $\mathbf{9 . 8 9}$ \\
Fatty Acids & - & - & - & 6.93 & 8.15 \\
Glycerides & - & - & - & - & - \\
Alcohols & - & - & - & 0.93 & 1.74 \\
\hline
\end{tabular}

Table A9. GC-MS analysis of the liquid products from the catalytic upgrading of brown grease (50 wt $\%$ in $\mathrm{C} 12$ ) over $20 \% \mathrm{Ni}-5 \% \mathrm{Cu} / \mathrm{Al}_{2} \mathrm{O}_{3}$ at $375{ }^{\circ} \mathrm{C}$ and WHSV $=0.8 \mathrm{~h}^{-1}$, in $100 \% \mathrm{H}_{2}$ for the second $100 \mathrm{~h}$. Text in bold corresponds to compound classes comprising the individual compounds listed. Text in italic corresponds to compound classes constituting the oxygenates detected.

\begin{tabular}{cccccc}
\hline Compound & $\mathbf{1 ~ h}$ & $\mathbf{2 4} \mathbf{h}$ & $\mathbf{4 8 ~ h}$ & $\mathbf{7 2} \mathbf{~ h}$ & $\mathbf{9 6} \mathbf{~ h}$ \\
\hline Normal Alkanes & $\mathbf{9 8 . 7 5}$ & $\mathbf{9 6 . 4 7}$ & $\mathbf{9 2 . 3 2}$ & $\mathbf{8 4 . 8 7}$ & $\mathbf{8 1 . 8 6}$ \\
Decane (C10) & 0.73 & 0.87 & - & - & - \\
Undecane (C11) & 0.73 & 0.81 & - & - & - \\
Tridecane (C13) & 0.94 & 1.54 & 1.18 & - & - \\
Tetradecane (C14) & 0.92 & 1.02 & 0.60 & - & - \\
Pentadecane (C15) & 17.13 & 16.53 & 17.73 & 19.15 & 18.08 \\
Hexadecane (C16) & 5.47 & 6.87 & 5.75 & 5.19 & 1.43 \\
Heptadecane (C17) & 52.39 & 47.07 & 44.18 & 41.35 & 44.50 \\
Octadecane (C18) & 13.78 & 16.89 & 16.32 & 13.11 & 12.59 \\
Nonadecane (C19) & 0.91 & 0.73 & 0.59 & 0.60 & 0.52 \\
Eicosane (C20) & 0.36 & 0.33 & 0.93 & - & - \\
Heneicosane (C21) & 0.53 & 0.32 & 0.31 & 0.48 & 0.40 \\
Docosane (C22) & 0.31 & 0.36 & 1.24 & 0.83 & - \\
Tricosane (C23) & 0.60 & 0.44 & 0.54 & 0.66 & 0.68 \\
Tetracosane (C24) & 0.56 & 0.43 & 0.49 & 0.75 & 0.56 \\
Pentacosane (C25) & 0.62 & 0.51 & 0.55 & 0.61 & 0.53 \\
Hexacosane (C26) & 0.75 & 0.71 & 0.78 & 0.87 & 0.87 \\
Heptacosane (C27) & 0.46 & 0.33 & 0.36 & 0.36 & 0.35 \\
Octacosane (C28) & 0.23 & 0.19 & 0.20 & 0.25 & 0.24 \\
Nonacosane (C29) & 0.22 & 0.19 & 0.21 & 0.23 & 0.16 \\
Triacontane (C30) & - & - & - & 0.09 & 0.23 \\
Hentriacontane (C31) & 0.21 & 0.17 & 0.21 & 0.20 & 0.27 \\
Tritriacontane (C33) & 0.21 & 0.16 & 0.18 & 0.16 & 0.26 \\
Pentatriacontane (C35) & 0.69 & - & - & - & 0.20 \\
Branched Alkanes & - & - & - & - & $\mathbf{0 . 2 7}$ \\
Cholestane & - & - & - & - & 0.16 \\
Stigmastane & - & - & - & - & 0.11 \\
\hline
\end{tabular}


Table A9. Cont.

\begin{tabular}{cccccc}
\hline Compound & $\mathbf{1 ~ h}$ & $\mathbf{2 4} \mathbf{~ h}$ & $\mathbf{4 8 ~ h}$ & $\mathbf{7 2} \mathbf{~ h}$ & $\mathbf{9 6} \mathbf{~ h}$ \\
\hline Olefins & $\mathbf{1 . 2 5}$ & $\mathbf{3 . 5 3}$ & $\mathbf{7 . 6 8}$ & $\mathbf{1 1 . 2 4}$ & $\mathbf{1 1 . 6 5}$ \\
4-decene (C10:1) & - & - & 1.07 & 1.19 & 0.44 \\
5-Undecene (C11:1) & - & - & 0.77 & 0.70 & 0.69 \\
Tridecene (C13:1) & - & - & - & 1.16 & 0.97 \\
2-Tetradecene (C14:1) & - & - & - & 0.87 & 0.93 \\
8-Heptadecene (C17:1) & 1.25 & 3.53 & 5.84 & 6.93 & 7.78 \\
1-Tetracosene (C24:1) & - & - & - & - & 0.16 \\
1-Pentacosene (C25:1) & - & - & - & - & 0.14 \\
1-Hexacosene (C26:1) & - & - & - & 0.16 & 0.24 \\
1-Heptacosene (C27:1) & - & - & - & 0.22 & 0.30 \\
Total Oxygenates & - & - & - & 3.89 & - \\
Fatty acids & - & - & - & 3.89 & 5.48 \\
Glycerides & - & - & - & - & - \\
Alcohols & - & - & - & - & 0.75 \\
\hline
\end{tabular}

\section{Appendix B}
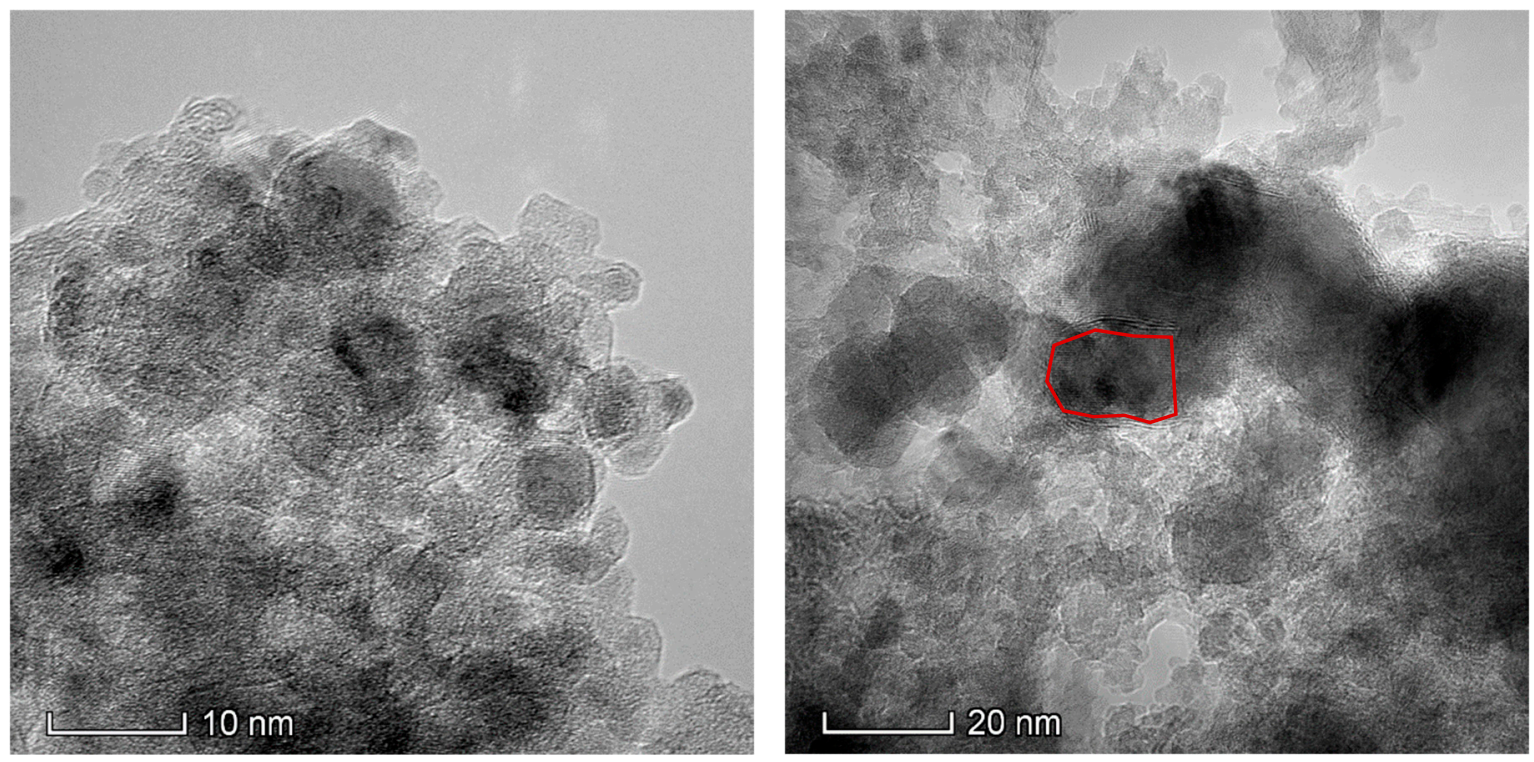

Figure A1. TEM micrographs of the fresh (left) and spent (right) catalyst. Distinct layers of carbonaceous deposits can be seen surrounding a metal particle in the spent catalyst outlined in red. 

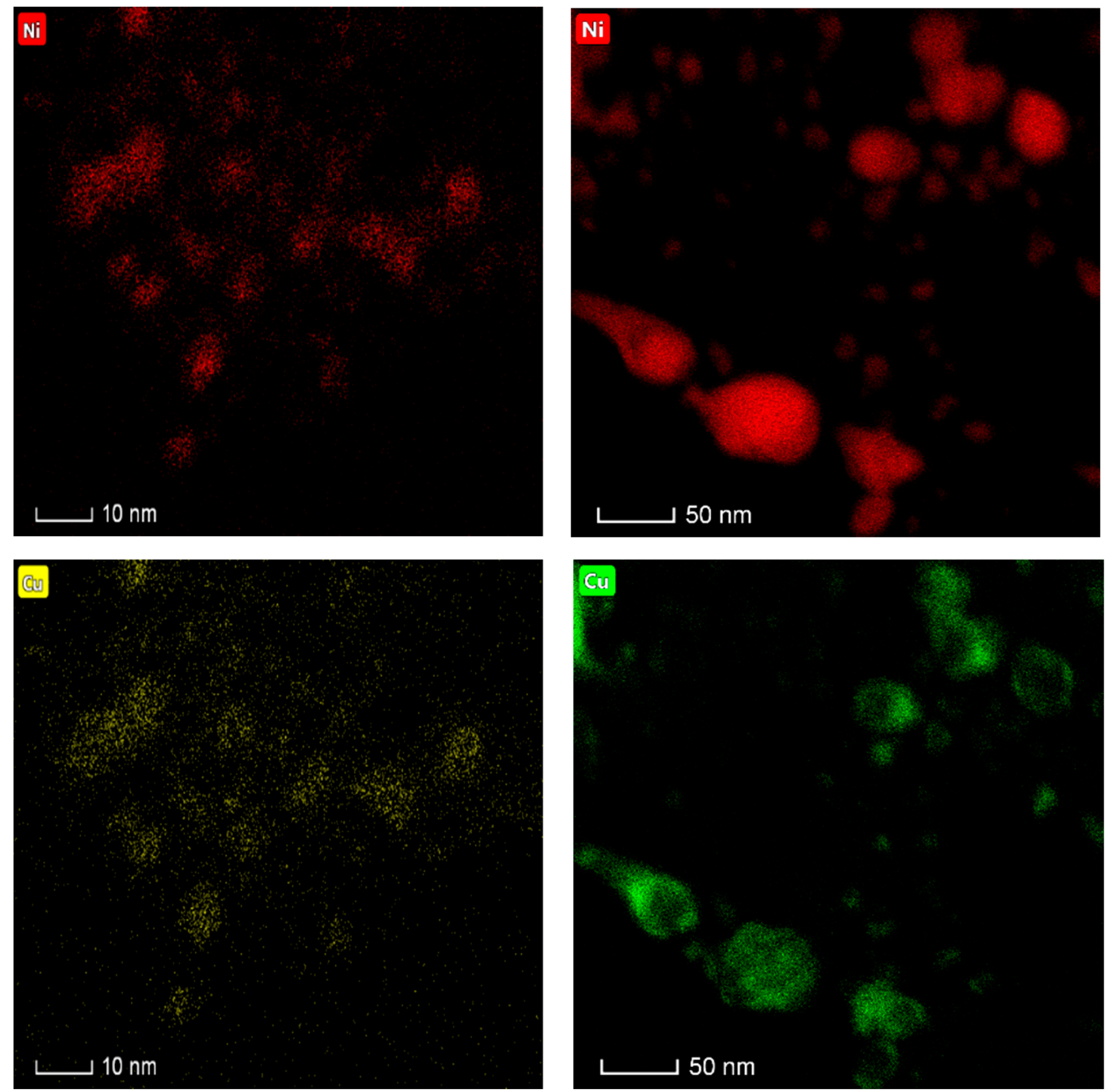

Figure A2. Elemental maps of fresh (left) and spent (right) catalyst showing both the formation of large particles during catalyst aging and the close association of $\mathrm{Ni}$ and $\mathrm{Cu}$ irrespective of the catalyst state (fresh or spent). 
a)

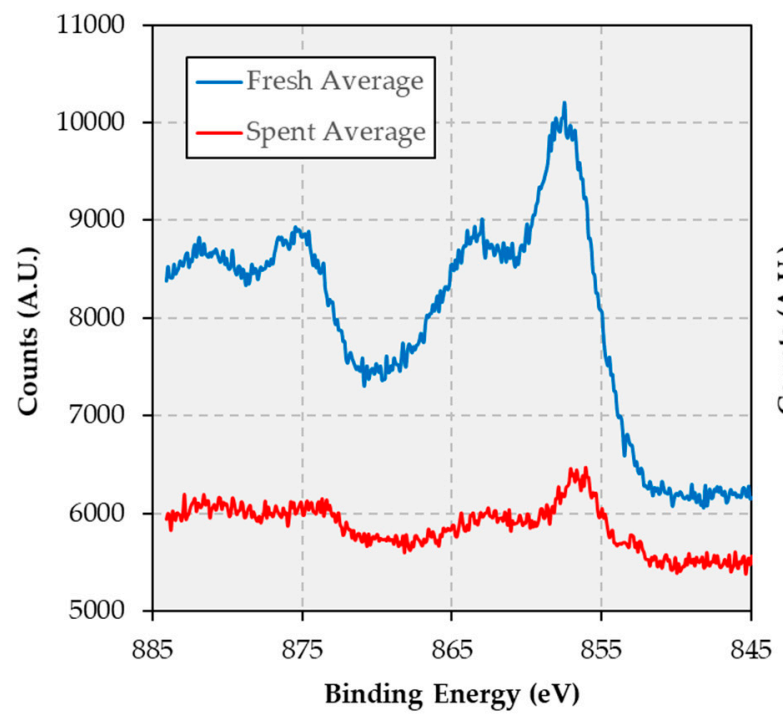

b)

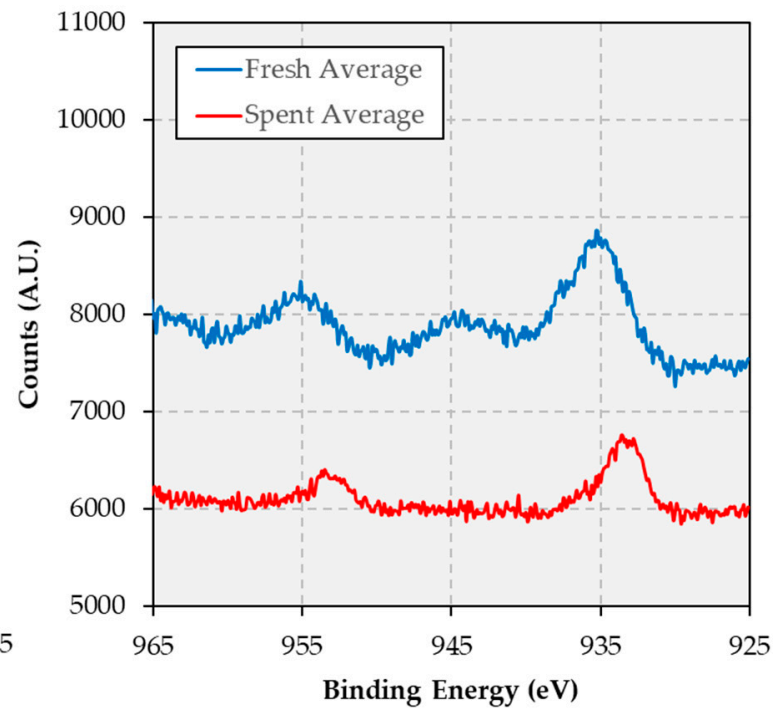

Figure A3. Nickel $2 p(a)$ and copper $2 p(b) x$-ray photoelectron spectra of the fresh and spent (after the second $100 \mathrm{~h}$ on stream) catalyst.

\section{References}

1. Tilman, D.; Hill, J.; Lehman, C. Carbon-negative biofuels from low-input high-diversity grassland biomass. Science 2006, 314, 1598-1600. [CrossRef] [PubMed]

2. Fargione, J.; Hill, J.; Tilman, D.; Polasky, S.; Hawthorne, P. Land clearing and the biofuel carbon debt. Science 2008, 319, 1235-1238. [CrossRef] [PubMed]

3. Pimentel, D.; Marklein, A.; Toth, M.A.; Karpoff, M.N.; Paul, G.S.; McCormack, R.; Kyriazis, J.; Krueger, T. Food versus biofuels: Environmental and economic costs. Hum. Ecol. 2009, 37, 1. [CrossRef]

4. Vásquez, M.C.; Silva, E.E.; Castillo, E.F. Hydrotreatment of vegetable oils: A review of the technologies and its developments for jet biofuel production. Biomass Bioenergy 2017, 105, 197-206. [CrossRef]

5. Bwapwa, J.K.; Anandraj, A.; Trois, C. Possibilities for conversion of microalgae oil into aviation fuel: A review. Renew. Sustain. Energy Rev. 2017, 80, 1345-1354. [CrossRef]

6. Chen, Y.; Wu, Y.; Hua, D.; Li, C.; Harold, M.P.; Wang, J.; Yang, M. Thermochemical conversion of low-lipid microalgae for the production of liquid fuels: Challenges and opportunities. RSC Adv. 2015, 5, 18673-18701. [CrossRef]

7. U.S. Department of Energy. Biofuels and Bioproducts from Wet and Gaseous Waste Streams: Challenges and Opportunities; EERE Publication and Product Library: Washington, DC, USA, 2017.

8. Knothe, G. Biodiesel and renewable diesel: A comparison. Prog. Energy Combust. Sci. 2010, 36, 364-373. [CrossRef]

9. Santillan-Jimenez, E.; Crocker, M. Catalytic deoxygenation of fatty acids and their derivatives to hydrocarbon fuels via decarboxylation/decarbonylation. J. Chem. Technol. Biotechnol. 2012, 87, 1041-1050. [CrossRef]

10. Kiméné, A.; Wojcieszak, R.; Paul, S.; Dumeignil, F. Catalytic decarboxylation of fatty acids to hydrocarbons over non-noble metal catalysts: The state of the art. J. Chem. Technol. Biotechnol. 2018. [CrossRef]

11. Mäki-Arvela, P.i.; Rozmysłowicz, B.; Lestari, S.; Simakova, O.; Eränen, K.; Salmi, T.; Murzin, D.Y. Catalytic deoxygenation of tall oil fatty acid over palladium supported on mesoporous carbon. Energy Fuels 2011, 25, 2815-2825. [CrossRef]

12. Jeništová, K.; Hachemi, I.; Mäki-Arvela, P.; Kumar, N.; Peurla, M.; Čapek, L.; Wärnå, J.; Murzin, D.Y. Hydrodeoxygenation of stearic acid and tall oil fatty acids over Ni-alumina catalysts: Influence of reaction parameters and kinetic modelling. Chem. Eng. J. 2017, 316, 401-409. [CrossRef]

13. Santillan-Jimenez, E.; Loe, R.; Garrett, M.; Morgan, T.; Crocker, M. Effect of Cu promotion on cracking and methanation during the Ni-catalyzed deoxygenation of waste lipids and hemp seed oil to fuel-like hydrocarbons. Catal. Today 2018, 302, 261-271. [CrossRef] 
14. Sari, E.; DiMaggio, C.; Kim, M.; Salley, S.O.; Ng, K.Y.S. Catalytic Conversion of Brown Grease to Green Diesel via Decarboxylation over Activated Carbon Supported Palladium Catalyst. Ind. Eng. Chem. Res. 2013, 52, 11527-11536. [CrossRef]

15. Laurent, E.; Delmon, B. Study of the hydrodeoxygenation of carbonyl, carboxylic and guaiacyl groups over sulfided $\mathrm{CoMo} / \gamma-\mathrm{Al}_{2} \mathrm{O}_{3}$ and $\mathrm{NiMo} / \gamma-\mathrm{Al}_{2} \mathrm{O}_{3}$ catalysts: I. Catalytic reaction schemes. Appl. Catal. A 1994, 109,77-96. [CrossRef]

16. Madsen, A.T.; Ahmed, E.H.; Christensen, C.H.; Fehrmann, R.; Riisager, A. Hydrodeoxygenation of waste fat for diesel production: Study on model feed with Pt/alumina catalyst. Fuel 2011, 90, 3433-3438. [CrossRef]

17. Stacy, C.J.; Melick, C.A.; Cairncross, R.A. Esterification of free fatty acids to fatty acid alkyl esters in a bubble column reactor for use as biodiesel. Fuel Process. Technol. 2014, 124, 70-77. [CrossRef]

18. Loe, R.; Santillan-Jimenez, E.; Morgan, T.; Sewell, L.; Ji, Y.; Jones, S.; Isaacs, M.A.; Lee, A.F.; Crocker, M. Effect of $\mathrm{Cu}$ and $\mathrm{Sn}$ promotion on the catalytic deoxygenation of model and algal lipids to fuel-like hydrocarbons over supported Ni catalysts. Appl. Catal. B 2016, 191, 147-156. [CrossRef]

19. Zhang, Z.; Yang, Q.; Chen, H.; Chen, K.; Lu, X.; Ouyang, P.; Fu, J.; Chen, J.G. In situ hydrogenation and decarboxylation of oleic acid into heptadecane over a $\mathrm{Cu}-\mathrm{Ni}$ alloy catalyst using methanol as a hydrogen carrier. Green Chem. 2018, 20, 197-205. [CrossRef]

20. Zhang, Z.; Chen, H.; Wang, C.; Chen, K.; Lu, X.; Ouyang, P.; Fu, J. Efficient and stable Cu-Ni/ZrO 2 catalysts for in situ hydrogenation and deoxygenation of oleic acid into heptadecane using methanol as a hydrogen donor. Fuel 2018, 230, 211-217. [CrossRef]

21. Peng, B.; Zhao, C.; Kasakov, S.; Foraita, S.; Lercher, J.A. Manipulating catalytic pathways: Deoxygenation of palmitic acid on multifunctional catalysts. Chem. Eur. J. 2013, 19, 4732-4741. [CrossRef]

22. Canakci, M. The potential of restaurant waste lipids as biodiesel feedstocks. Bioresour. Technol. 2007, 98, 183-190. [CrossRef] [PubMed]

23. Kim, M.; DiMaggio, C.; Yan, S.; Wang, H.; Salley, S.O.; Ng, K.S. Performance of heterogeneous $\mathrm{ZrO}_{2}$ supported metaloxide catalysts for brown grease esterification and sulfur removal. Bioresour. Technol. 2011, 102, 2380-2386. [CrossRef] [PubMed]

24. Kubičková, I.; Snåre, M.; Eränen, K.; Mäki-Arvela, P.; Murzin, D.Y. Hydrocarbons for diesel fuel via decarboxylation of vegetable oils. Catal. Today 2005, 106, 197-200. [CrossRef]

25. Sugami, Y.; Minami, E.; Saka, S. Renewable diesel production from rapeseed oil with hydrothermal hydrogenation and subsequent decarboxylation. Fuel 2016, 166, 376-381. [CrossRef]

26. Santillan-Jimenez, E.; Morgan, T.; Shoup, J.; Harman-Ware, A.; Crocker, M. Catalytic deoxygenation of triglycerides and fatty acids to hydrocarbons over Ni-Al layered double hydroxide. Catal. Today 2014, 237, 136-144. [CrossRef]

27. Santillan-Jimenez, E.; Morgan, T.; Lacny, J.; Mohapatra, S.; Crocker, M. Catalytic deoxygenation of triglycerides and fatty acids to hydrocarbons over carbon-supported nickel. Fuel 2013, 103, 1010-1017. [CrossRef]

28. Couble, J.; Gravejat, P.; Gaillard, F.; Bianchi, D. Quantitative analysis of infrared spectra of adsorbed species using transmission and diffuse reflectance modes: Case study: Heats of adsorption of $\mathrm{CO}$ on $\mathrm{TiO}_{2}$ and $\mathrm{CuO} / \mathrm{Al}_{2} \mathrm{O}_{3}$. Appl. Catal. A 2009, 371, 99-107. [CrossRef]

29. Kordouli, E.; Pawelec, B.; Kordulis, C.; Lycourghiotis, A.; Fierro, J. Hydrodeoxygenation of phenol on bifunctional Ni-based catalysts: Effects of Mo promotion and support. Appl. Catal. B 2018, 238, 147-160. [CrossRef]

30. Chen, H.; Zhang, X.; Zhang, J.; Wang, Q. Tuning Decarboxylation Selectivity for Deoxygenation of Vegetable Oil over Pt-Ni Bimetal Catalysts via Surface Engineering. Catal. Sci. Technol. 2018, 8, 1126-1133. [CrossRef]

31. Van Stiphout, P.; Stobbe, D.; Scheur, F.T.V.; Geus, J. Activity and stability of nickel-copper/silica catalysts prepared by deposition-precipitation. Appl. Catal. 1988, 40, 219-246. [CrossRef]

32. Kishi, K.; Sasanuma, M. The interaction of $\mathrm{O}_{2}$ with $\mathrm{Cu} / \mathrm{Ni}(100)$ and $\mathrm{Cu} / \mathrm{NiO} / \mathrm{Ni}(100)$ surfaces studied by XPS. J. Electron. Spectrosc. Relat. Phenom. 1989, 48, 421-434. [CrossRef]

33. Naghash, A.; Etsell, T.; Xu, S. XRD and XPS study of Cu-Ni interactions on reduced copper-nickel-aluminum oxide solid solution catalysts. Chem. Mater. 2006, 18, 2480-2488. [CrossRef]

34. Hüfner, S.; Wertheim, G.K.; Cohen, R.L.; Wernick, J.H. Density of States in CuNi Alloys. Phys. Rev. Lett. 1972, 28, 488-490. [CrossRef]

35. Biesinger, M.C. Advanced analysis of copper X-ray photoelectron spectra. Surf. Interface Anal. 2017, 49, $1325-1334$. [CrossRef] 
36. Webber, P.; Rojas, C.; Dobson, P.; Chadwick, D. A combined XPS/AES study of Cu segregation to the high and low index surfaces of a Cu-Ni alloy. Surf. Sci. 1981, 105, 20-40. [CrossRef]

37. Kordulis, C.; Bourikas, K.; Gousi, M.; Kordouli, E.; Lycourghiotis, A. Development of nickel based catalysts for the transformation of natural triglycerides and related compounds into green diesel: A critical review. Appl. Catal. B 2016, 181, 156-196. [CrossRef]

38. Goldberger, W.M.; Othmer, D. Kinetics of nickel carbonyl formation. Ind. Eng. Chem. Process De. Dev. 1963, 2, 202-209. [CrossRef]

39. Morgan, T.; Santillan-Jimenez, E.; Huff, K.; Javed, K.R.; Crocker, M. Use of dual detection in the gas chromatographic analysis of oleaginous biomass feeds and biofuel products to enable accurate simulated distillation and lipid profiling. Energy Fuels 2017, 31, 9498-9506. [CrossRef]

C 2019 by the authors. Licensee MDPI, Basel, Switzerland. This article is an open access article distributed under the terms and conditions of the Creative Commons Attribution (CC BY) license (http://creativecommons.org/licenses/by/4.0/). 